The Journal of Private Enterprise 25(2), 2010, 1-53

\title{
Israel Kirzner on Coordination and Discovery
}

\author{
Daniel B. Klein and Jason Briggeman* \\ George Mason University
}

\begin{abstract}
Israel Kirzner has been a leader in fashioning an Austrian school of economics. In his rendering of the Austrian school, one finds a marriage between Friedrich Hayek's discourse with Ludwig von Mises's deductive, praxeological image of science - a marriage that seems to us somewhat forced. The Misesian image of science stakes its claims to scientific status on purported axioms and categorical, 100 percent deductive truths, as well as the supposed avoidance of any looseness in evaluative judgments. In keeping with the praxeological style of discourse, Kirzner claims that his notion of coordination can be used as a clear-cut criterion of economic goodness. Kirzner wishes to claim that gainful entrepreneurial action in the market is always coordinative. We contend that Kirzner's efforts to be categorical and to avoid looseness are unsuccessful. We argue that looseness is inherent in the economic discussion of the most important things, and associate that viewpoint with Adam Smith. We suggest that Hayek is much closer to Smith than to Mises, and that Kirzner's invocations of Hayek's discussions of coordination are spurious. In denying looseness and trying to cope with the brittleness of categorical claims, Kirzner becomes abstruse. His discourse erupts with problems. Kirzner has erred in rejecting the understanding of coordination held by Hayek, Ronald Coase, and their contemporaries in the field at large. Kirzner's refraining from the looser Smithian perspective stems from his devotion to Misesianism. Beyond all the criticism, however, we affirm the basic thrust of what Kirzner says about economic processes. Once we give up the claim that voluntary profitable activity is always or necessarily coordinative, and once we make peace with the aesthetic aspect of the idea of concatenate coordination, the basic claims of Kirzner can be salvaged: Voluntary profitable activity is usually coordinative, and government intervention is usually discoordinative. But the Misesian image of science must be dropped.
\end{abstract}

JEL Codes: A10, B00, C7, D2

Keywords: Coordination; Concatenation; Discovery; Entrepreneurship

* We thank Niclas Berggren, Gene Callahan, Peter Klein, Frederic Sautet, George Selgin, and Ed Stringham for valuable comments. Jason Briggeman thanks the Mercatus Center at George Mason University for a summer fellowship to complete this study. 


\section{Introduction}

Israel Kirzner is best known for his work on the role of discovery and entrepreneurship in economic affairs. He sees entrepreneurial alertness as the vital human faculty to apprehend opportunities for one's betterment. Entrepreneurial discovery entails interpretive shifts and awakenings. It goes beyond the deliberate search for or mechanical response to new information. Kirzner's insights about discovery are in contrast to the kind of economics that regards human beings as interpretively flat and fixed - that is, working within an unchanging understanding of their own ends and means. Game theory typically assumes common knowledge - interpretational symmetry throughout the "game." Knowledge is flattened down to information: There is no heterogeneity of interpretations and no role for judgment over interpretations. If economists confine their thinking to stories of final and symmetric interpretation, they will under-appreciate the role of discovery and entrepreneurship in economic affairs. More specifically, they will fail to do justice to laissez-faire (Kirzner, 1985).

Kirzner strives to integrate his discovery ideas into theories of market coordination. Refining ideas at both ends - discovery and coordination - Kirzner works to maintain that, in market activity, successful voluntary entrepreneurial action necessarily enhances coordination.

Our attitude toward Kirzner is great admiration mixed with frustration and regret. We embrace the central teachings - notably, that successful entrepreneurship and voluntary activity more generally usually enhance coordination, and, even more typically, that restrictions on voluntary activity diminish coordination. We are thoroughly supportive of those broad themes developed and expounded by Kirzner.

We feel, however, that Kirzner has made errors. Our impetus is to strengthen the central teachings by identifying and correcting the errors. Greater robustness of the central claims - that entrepreneurship, that freedom conduces to better coordination - is achieved by two sorts of changes. First, in certain respects the claim must be weakened. Kirzner makes "always"- or "necessarily"-type claims - categorical claims - where the claims instead should be "usually" or "by and large." Second, changes are needed in the formulation and semantics. Suitably tailored, the chief messages still ring out but become looser. Broadly speaking, our approach is greater robustness through greater looseness. 
If we basically agree with Kirzner's teachings, then why the disagreements? We begin by offering a broad interpretation of why Kirzner would develop the ideas in ways we deem erroneous.

\section{Mises, Kirzner, and the Project of Austrianism}

Kirzner has been a leader in building an Austrian identity within economics. The narrative makes Ludwig von Mises the central figure of the Austrian tradition, although the tradition is said to originate with Carl Menger. In Kirzner's view, Friedrich Hayek also looms large, but Hayek is thought to develop the economics of Mises. Kirzner and his followers tend to homogenize Hayek and Mises.

Although Mises and Kirzner declare their economics to be "value free" (or "wertfre?"), it is clear that they believe that economics ought to address the most important things, notably major policy issues, and that they believe that the economics profession and public culture poorly appreciate laissez-faire. It is clear that Mises, Hayek, and virtually all self-described Austrian economists are motivated to advance classical liberalism, but that impetus is not distinctive to Mises, Hayek, and the self-described Austrians. If there is to be a distinctive Austrian identity, it must draw on other elements.

Kirzner sees Austrian distinctiveness in the praxeology of Mises, who propounded a view of economics as a science built on fundamental, a priori axioms of human action. Mises ascribes to his praxeology a truth status like that of mathematics:

The theorems attained by correct praxeological reasoning are not only perfectly certain and incontestable, like the correct mathematical theorems. They refer, moreover, with the full rigidity of their apodictic certainty and incontestability to the reality of action as it appears in life and history. Praxeology conveys exact and precise knowledge of real things. (Mises, 1966, p.39)

It is upon a supposed status of axiomatic foundation, logical deduction, and apodictic certainty that Mises and those who have promulgated an Austrian identity, led by Kirzner and Murray Rothbard, stake their claim for a distinct science of economics, a science that happens to support libertarian conclusions.

Hayek, however, never embraced Mises's approach and never promulgated an Austrian identity. Compared to Mises, Hayek is 
considerably looser and more pragmatic - and pragmatist. We think Hayek is closer to, say, Adam Smith and Edwin Cannan, than to Mises. Hayek sees economics not as an exact or deductive science but as part of the civilization's general cultural purpose, and hence as framed by the civilization's notions of the good. Hayek (1978a) said: "Mises himself was still much more a child of the rationalist tradition of the Enlightenment and of continental, rather than of English, liberalism...than I am myself."

"[T] he diverging interests of [Mises and Hayek]," suggest Keith Jakee and Heath Spong (2003, p.473), "is potentially relevant to the disunity that has surfaced within the Austrian school since the 1970s." They relate that divergence to tensions in Kirzner's discourse, particularly between the Misesian image of science and the theories about entrepreneurship. ${ }^{2}$

The wing of Austrianism associated more closely with the ideas of Murray Rothbard and with the Ludwig von Mises Institute clearly elevates Mises (and Rothbard) above the squishy Hayek. In "Mises and Hayek Dehomogenized," the Rothbardian Austrian Joseph T. Salerno (1993) argues that Hayek is importantly different than Mises. The wing more associated with Kirzner and Peter Boettke, however, tends to homogenize Mises and Hayek. Many of Kirzner's followers seem to subscribe to the homogenization and to Kirzner's writings on coordination (for example, Ikeda, 1990; Thomsen, 1992; Sautet, 2000; Boettke, 2001).

While earning an MBA at New York University during the 1950s, Kirzner encountered Mises and his private seminar. Kirzner was captivated and, along with Rothbard, became a leading protégé. Working under Mises, Kirzner earned his Ph.D. in economics at NYU in 1957. Throughout his career, Kirzner has remained loyal to Mises's conception of "the pure, universal truths of economic

\footnotetext{
${ }^{1}$ Hayek made related remarks about Mises's undue rationalism and emphasis on the a priori in an interview published in Hayek on Hayek (Hayek, 1994, p.72-73) and in his foreword to Mises's Socialism (Hayek, 1978b, xxxiii).

2 There is much congruence between our views and those of Jakee and Spong (2003). They are skeptical of the homogenization of Mises and Hayek, and would seem to favor Hayek. Also, they repeatedly make an issue of a distinction that seems to track ours, presented below, between plan fulfillment and retrospective plan affirmation (p.477 n.24, p.480-81, p.482 n.32). They, however, seem to enter into the dubious practices of speaking of equilibrium, equilibration, etc., without reference to a model (e.g., p.474-78), and of speaking of equilibrium and coordination apparently as though they were interchangeable (e.g., p.480).
} 
theory" (Kirzner, 2001, p.56), or Mises' image of science. We contend, like Jakee and Spong (2003, p.470-73), that Kirzner has been committed to building a distinctive Misesian science of economics.

Kirzner has produced extensive discourse, in which a central word is coordination. Kirzner (2000, p.133) writes that coordination is "a clear-cut, objective criterion... which may satisfy the intuitive conviction of economists that their science does objectively demonstrate the economic 'goodness' of some economic policies." Thus, for Kirzner, coordination signifies economic goodness. He claims to show that voluntary, successful entrepreneurial action in the market necessarily advances coordination or is coordinative. Notice the two important features: The claim is categorical, or 100 percent that is the nature of praxeological truth and, to Misesians, the mark of economic science. Second, the claim lends support to (though does not seal the case for) libertarian policy, for to obstruct such entrepreneurial action, as with government restrictions, would be to prevent coordinative actions.

To our thinking, Mises, Rothbard, and Kirzner are alike in their image of science. Coordination does not play a large role in Mises and Rothbard, but Kirzner makes great efforts to develop the concept of coordination in order to integrate teachings of economic liberalism with Mises's image of science. In contrast, Smith and Hayek may be said to advance the teachings of economic liberalism in ways that mostly avoid modernist conceptions of such discourse.

\section{Concatenate Coordination: Hayek, Coase, and so on}

Along with other economists of their times, Mises and Hayek used the term coordination in the sense of "concatenate coordination," an appellation used by Klein and Orsborn (2008) in order to distinguish it from the "mutual coordination" of later discourse following Thomas Schelling and game theory. Klein and Orsborn make a systematic investigation of how economists have used the term coordination. They suggest that, until around 1970, the way that economists used coordination is best understood in the following way: A concatenation of activities and resources is coordinated to the extent that the concatenation would be satisfying, pleasing, or even beautiful to a mind imagined to behold it. Hayek's usage of coordination nicely fits this understanding, but Kirzner (2000, ch.10) contends that his coordination is true to Hayek's. We wish to 
disentangle concatenate coordination from some of Kirzner's characterizations of coordination and hence will dwell a bit on concatenate coordination.

Up to around 1930, the primary economic talk of "coordination," aside from usage in the transportation literature, concerned the concatenation of activities within the firm. But in the 1930s a new moment occurred that may be marked by a lecture given by Friedrich A. Hayek in 1933 at the London School of Economics (LSE) and published that year in Economica as "The Trend of Economic Thinking." Hayek takes coordination to the extensive economic cosmos. This step was not entirely novel, ${ }^{3}$ but it now becomes prominent in Anglo-American economics. The LSE during the 1930s seems to have bubbled with talk of coordination beyond the firm.

In the lecture Hayek extends the idea of concatenate coordination beyond the eye of any actual coordinator:

From the time of Hume and Adam Smith, the effect of every attempt to understand economic phenomena - that is to say, of every theoretical analysis - has been to show that, in large part, the co-ordination of individual efforts in society is not the product of deliberate planning, but has been brought about, and in many cases could only have been brought about, by means which nobody wanted or understood, and which in isolation might be regarded as some of the most objectionable features of the system. (Hayek, 1933a, p.129; emphasis added)

Hayek is describing independent actions that lead to outcomes beyond the actor's intention and comprehension - spontaneous order. Like the concatenate coordination within the firm,

\footnotetext{
${ }^{3}$ Such usage occurs notably by Herbert Spencer, who in First Principles (1862) used the term coordination in drawing biological analogies. Besides some writers who made biological analogies similar to those of Spencer, the searches by Klein and Orsborn find other scattered and fleeting occurrences of "coordination" meaning spontaneous concatenate coordination in works by Henry George, John Bates Clark, Philip Wicksteed, Ludwig von Mises, David Friday, Lawrence Frank, Raymond Bye, and Shorey Peterson. These are shown in worksheets available from the authors or at http://www2.sofi.su.se/ 1st/docs/KleinOrsborn_Coordination_in_HET2.xls.
} 
coordination means desirable arrangement or outcome. But, desirable to whom?

The matter, Hayek emphasizes, calls for great delicacy:

The limitations of language make it almost impossible to state it without using misleading metaphorical words. The only intelligible form of explanation for what I am trying to state would be to say - as we say in German - that there is sense [Sinn] in the phenomena; that they perform a necessary function. But as soon as we take such phrases in a literal sense, they become untrue. It is an animistic, anthropomorphic interpretation of phenomena, the main characteristic of which is that they are not willed by any mind. And as soon as we recognize this, we tend to fall into an opposite error, which is, however, very similar in kind: we deny the existence of what these terms are intended to describe. (1933a, p.27; emphasis added to the final sentence)

Hayek would steer us away from that "opposite error." $\mathrm{He}$ suggests that society has a "sense" like an "organism." He even writes that a notion of social organism is necessary to economics: "The recognition of the existence of this organism is the recognition that there is a subject matter for economics" (1933a, p.27). Yet he makes these suggestions with great caution. Classical liberals dread the hazards of any society-as-organism metaphor. ${ }^{4}$ The lecture is quite remarkable as an early expression of the dilemmas in opposing society-as-organization notions while trying to say that liberal processes are coordinative. But, coordinative to whom? In the case of the firm, an answer is fairly clear - the owners/managers. But for a polycentric spontaneous system, there is no tangible analog.

The way to interpret the "sense" of the social "organism" of which Hayek spoke is to think of a fictitious mind able to behold the extensive tapestry of social affairs, in principle including future generations, and inclined to judge it in a manner that parties to the discourse are presumed to find acceptable. This imagined judge is like that being whose hands, according to Adam Smith, are invisible. Alluding to Hume and Smith, Hayek too wants to talk about

\footnotetext{
${ }^{4}$ Like Hayek, Simon Newcomb (1886, p.7-8) articulates cautions while going
} forward with the organism metaphor. 
coordination beyond the eye of any actual human coordinator. This understanding of coordination comports perfectly with the dictionary definition of the transitive verb to coordinate, to put things into a pleasing order or arrangement. Necessarily embedded within such understanding are aesthetic or moral sensibilities relevant to the interlocutors. The understanding thus involves deep dimensions that are, in Adam Smith's words, "loose, vague, and indeterminate" (1790, p.175, p.327).

In writing of society as organism, Hayek cites the 1923 and 1932 German language editions of Mises' Socialism (1981), which not only affirms the notion of the social organism but uses it very extensively (as may be easily confirmed by an electronic text search). Interestingly, in Mises's later magnum opus Human Action (1966, p.589) there is but a single, insignificant instance of such usage. The disappearance reflects deep changes in Mises's intellectual enterprise; as Kirzner (2001, p.54) notes: "Mises' distinctiveness had not yet been firmly established by 1930." Further, it should be recalled that Hayek entered intellectual maturity as a mild socialist and a pupil of Friedrich von Wieser, whose works burble with notions akin to social organism (Shearmur, 1996, ch.2). Hayek (1978a) noted that he had come from Wieser and that Mises "gradually, but never completely, won me over." It is true that Mises converted Hayek on economic policy, but there is no reason to suppose that Mises drove organism metaphors from Hayek's mind, particularly as at the time Mises himself was expounding on them. Hayek said that "[Mises's] Socialism told us [young idealists] that we had been looking for improvement in the wrong direction" (Hayek, 1978b, p.xix) - not that the book transformed their idea of improvement.

Coordination ideas were explored at the LSE by Hayek's colleagues W.H. Hutt (1934), Arnold Plant (1937), and Ronald Coase (1937). Coase posed his problem: "In view of the fact that, while economists treat the price mechanism as a co-ordinating instrument, they also admit the co-ordinating function of the 'entrepreneur,' it is surely important to enquire why co-ordination is the work of the price mechanism in one case and of the entrepreneur in another" (1937, p.389). Hayek's idea of coordination was apparently no different from that of Coase and many other economists. Yet Kirzner develops claims about coordination that he presents as true to Hayek and part of a distinctively Austrian sort of economics. 


\section{Kirzner's Coordination Often Seems Like Concatenate Coordination}

A great many of Kirzner's statements about coordination read fine as concatenate coordination. Early in his career, he described the price system as a coordinative force in society: "Clearly, with innumerable producers making independent decisions as to production techniques, the economy must coordinate these decisions so as to ensure that each producer uses those resources least needed elsewhere in the economy....An efficient system will provide sufficient reward to each participant to enable all participants to enjoy the benefits of the widest possible range of resource services" (1963, p.38). Elsewhere, Kirzner writes: "Within the firm, activities are coordinated by central direction, not by market competition via a price mechanism" (1992a, p.161).

Indeed, we find Kirzner articulating the construct of a mind imagined to behold the vast concatenation and its potentialities, as when he writes that the actions of buyers and sellers who have not noticed certain profit opportunities "are, from the perspective of omniscience, uncoordinated and inconsistent" (1985, p.59; emphasis added), or when speaking of coordinating traffic flow: "Were an omniscient single mind to make the decisions for all the drivers, that mind might arrange the drivers' actions in a smooth and safe fashion" (1992a, p.140; first emphasis added).

Because we believe that concatenate coordination conforms to the coordination discussed by Herbert Spencer, Simon Newcomb, Mises, Hayek, Coase, and hundreds of others, we think it is significant that a great many of Kirzner's utterances about coordination might be read that way. It gives the reader the impression that Kirzner is adhering to conventional usage, and it allows Austrians to speak to wider audiences. Our view, again, is that the coordination talk among Austrians ought to become sensibly about concatenate coordination - but, again, doing so would upset their claim to distinctiveness in the matter. In earlier work, Klein (1997a) proposed that Kirzner's basic claims be understood as byand-large claims about concatenate coordination, but this proposal was vigorously resisted by Kirzner (2000, p.132-148, p.199).

\section{Kirzner's Troubled Claims about Coordination}

Kirzner's discourse has come to center around "coordination." Kirzner introduces and attempts to reconcile a jumble of claims 
about coordination. Before addressing the problems, we lay out the pieces that Kirzner attempts to fit together.

Two background conditions should be clarified. In speaking of whether economic actions are coordinative, Kirzner does not mean burglary, fraud, and other coercive actions (e.g., Kirzner 1992b, p.93); he confines the discourse to voluntary action. Second, Kirzner means entrepreneurial action that is successful, in the sense that the agent does not feel that his entrepreneurial action was an error but rather that it was gainful. Kirzner acknowledges that actors may make losses and feel regret, and that such voluntary acts might be discoordinative. His statements concern the coordinative aspects of the successful entrepreneurial seizing of gainful opportunities (e.g., Kirzner, 1992a, p.21-31). Kirzner is on solid ground in supposing that markets do not tend toward specific agent errors, and do tend to weed out lossmaking activity and to correct agent errors (2000, p.31), so it is appropriate to focus on successful entrepreneurial action in characterizing market tendencies. Although there are issues about which actions are to be deemed entrepreneurial, we, too, mean such actions that are voluntary and successful.

\section{A. "Every Entrepreneurial Gain is Coordinative"}

The great virtue of Kirzner's coordination discourse is the emphasis he places on discovery, on the idea that new discoveries of gainful activities represent advances in coordination - a point too often neglected by formalistic economists and by interventionists who presume that regulators can know the economy and its potentialities well enough to manipulate it beneficially. We salute Kirzner (1992a, p.151) when he writes that entrepreneurial discoveries constitute "steps through which markets tend to achieve co-ordination, gradually replacing earlier states of widespread mutual ignorance by successively better co-ordinated states of society." Concatenate coordination will typically recognize such discovery as coordination: A humane liberal mind imagined to behold the vast tapestry and its potentialities normally will smile upon the discovery of such opportunities.

But the Misesian image of science leads Kirzner to make strong claims about the relation between coordination and the discovery of such opportunities. He maintains that every instance of discovering and seizing gainful opportunity advances coordination, and, inversely, 
every unexploited opportunity represents a failure in coordination, as shown by the following quotations:

- "to identify absences of coordination among the plans of market participants it is sufficient to identify profit opportunities" (1973, p.222; emphasis added).

- "where an unexploited mutually beneficial exchange opportunity for A and B exists, the resulting 'inefficiency' can be described as an absence of coordination" (1973, p.216).

- Kirzner suggests that all profit opportunities are "created by initial discoordination" (2000, p.21).

- Kirzner asserts that market entrepreneurship always advances coordination when he refers to "a possibly faulty functioning of the market" as "a possibility we have denied" (2000, p.86).

So Kirzner frequently says that market entrepreneurship is always coordinative. There is another issue worth clarifying before proceeding: In assessing whether an entrepreneurial action enhances coordination, what is the comparison? What is the hypothetical alternate concatenation? How do we characterize the concatenation without the entrepreneurial event? Like Kirzner, we focus on the discovery of opportunity. We suggest that usually the most relevant alternate concatenation is to imagine that for some adventitious reason the actor misses the opportunity. Imagine that an extraneous, unwelcome distraction interrupted the moment of discovery, preventing (or perhaps delaying) the actor's discovery of the opportunity, and, in consequence, after getting past the distraction he goes about his affairs without any really usable apprehension or formulation of the opportunity - without any sense of having "gotten an idea." In the case of distraction, we don't know exactly what would happen or how coordinative that world would be - possibly, the entrepreneurial action in question would itself have been a distraction to an even better discovery, which is now realized by virtue of the adventitious distraction that blocks the lesser discovery - after all, there is usually an even better opportunity out there. We resort to supposing, however, that without discovering the opportunity in question the actor instead carries out actions that are more obvious, closer to routine. With Kirzner, we say that there is no tendency to 
experience one discovery when a merely adventitious distraction would have brought one to an even better discovery - otherwise people would invite random distractions. It could happen, of course, but it would be somewhat aberrant. Accordingly, for our perspective as social analysts, the "expected" concatenation of the world without the discovery is more commonplace than the world with the discovery, more like "the day before" in the relevant context. It is a world without the "development" of the new discovery.

\section{B. "Coordination is the Fulfillment or Compatibility of Plans or Expectations"}

Kirzner (2000, p.190) characterizes coordination "as the state (or the process leading towards the state) in which the individual plans of independently-acting persons display mutual compatibility. Such compatibility may be couched, as in the preceding sentence, in terms of plans, or it may be couched in terms of decisions, or of expectations." He adds, "The fundamental idea in this coordination concept is that we (the economic or social scientists) are interested in the extent to which the decisions made by an individual correctly anticipate (and take advantage of) the decisions in fact being made by others" (2000, p.191).

Elsewhere Kirzner offers the following characterization: "A fully coordinated state of affairs, for our purposes, is one in which each action taken by each individual in a demarcated set of actions correctly takes into account (a) the actions in fact being taken by everyone else in the set, and (b) the actions which the others might take were one's own actions to be different" (2000, p.136; emphasis added).

Kirzner inversely characterizes discoordination as involving discordance, disappointment, or regret: "disappointment and/or regret...must ultimately ensue from patterns of action which incorrectly anticipate and depend upon the actions of others in the system" (2000, p.145); "The entrepreneurial-competitive process becomes visible... as discovering and correcting discordant individual plans and decisions" (1973, p.218).

Notice that Kirzner has run together two perspectives that entail different sets of sentiments. One perspective regards how things go along a chosen plan (or projected path of action), the positive sentiment there being fulfillment and the negative being frustration or disappointment. The other perspective regards retrospectively the chosen path as opposed to some could-have-been alternate path, the positive sentiment being affirmation of the choice one made and the 
negative being regret or self-reproach. For example, an employer hires Meg and it all goes fine and as expected, the plan is fulfilled, but once the action is irreversible the employer realizes that he could have offered the job to Valerie, who likely would have accepted and been better, and he feels he should have thought of that. This would be a case of fulfillment of the plan but nonetheless regret and an introspective sense of error. Our distinction seems to correspond to ones presented by Jakee and Spong (2003, p.477 n.24, p.480-81, p.482 n.32 referring to Jack High 1982), who argue that Kirzner's idea of entrepreneurial alertness "becomes overly elastic and therefore must carry too much of his argument" (p.480). We, too, contend that Kirzner blurs the distinction, which is elaborated in Table 1.

\section{Table 1: Two Perspectives about a Plan: Fulfillment vs. Retrospective Affirmation}

\begin{tabular}{l|c|c|}
\multicolumn{1}{c}{} & \multicolumn{1}{c}{ Positive } & Negative \\
\cline { 2 - 3 } $\begin{array}{l}\text { Sentiment along the } \\
\text { path pursued }\end{array}$ & $\begin{array}{c}\text { Fulfillment } \\
\text { Compatibility }\end{array}$ & $\begin{array}{c}\text { Disappointment, } \\
\text { frustration }\end{array}$ \\
\cline { 2 - 3 } & Affirmation & Discord \\
$\begin{array}{l}\text { Sentiment looking } \\
\text { back on the path } \\
\text { pursued, as opposed } \\
\text { to some alternate path }\end{array}$ & Regret, self-reproach \\
& $\begin{array}{c}\text { Error, according to } \\
\text { Klein (1999) and } \\
\text { sometimes Kirzner }\end{array}$ \\
\hline
\end{tabular}

Kirzner also uses the term "dovetailing" to express the positive aspects of coordination, as when he says: "Co-ordination does not refer to the well-being achieved through its successful attainment; it refers only to the dovetailing character of the activities that make it up" (1992a, p.185, 191; see also 2000, p.183, p.196). He even says that "dovetailing" is the "earmark" of coordination (2000, p.190). Later we discuss Kirzner's usage of the term "dovetailing."

C. "Coordination Makes No Resort to Social Aggregation" 
Kirzner insists that the coordination criterion "relies not at all on any notions inconsistent with subjectivism or with methodological individualism" (1992a, p.185); "The coordination criterion does not purport to say anything whatever about aggregate well-being" (2000, p.144); "It is possible to evaluate a system of social organization's success in promoting the coordination of the decisions of its individual members without invoking any notion of social welfare at all" (1973, p.216). ${ }^{5}$

\section{Diagram of Three Rubrics}

A two-step process at work in Kirzner, by which he asserts that Hayek (and Mises) really meant what Kirzner means by "coordination." Let us explain with reference to Table 2.

Rubric I: Here is concatenate coordination, and here is where Mises and Hayek properly belong. When they spoke of coordination, they almost always meant concatenate coordination. The occurrences of coordination are few in Mises and abundant in Hayek. ${ }^{6}$ The meaning is clearly concatenate. Note that "coordination" did not play a significant role in Mises's propounding of praxeology, so, while we reject that propounding, we see no particular problem in Mises's usage of coordination. ${ }^{7}$

Rubric II: Here is a Kirznerian coordination wherein expectations/plans are fulfilled, compatible, or affirmed. We noted earlier that there is actually quite a lot floating around in Kirzner's utterances about fulfillment, compatibility, and affirmation, or - to take them in their negations - disappointment, incompatibility, and regret. The variations here have to do with the distinction between what happens along a path of action (or plan) and how one regards

\footnotetext{
${ }^{5}$ Hayek at times invokes aggregation quite readily, for example: "the ordering and productivity enhancing function of prices, and particularly the prices of services, depends on their informing people where they will find their most effective place in the overall pattern of activities - the place in which they are likely to make the greatest contribution to aggregate output" (1978c, p.63).

${ }^{6}$ These are shown in worksheets available from the authors or at: http://www2.sofi.su.se/ 1st/docs/Klein-Orsborn_Coordination_in_HET2.xls. 7 Kirzner (2000, p.198) writes: "Now Mises himself never did focus explicitly on plan-coordination in all of his work; he never did focus on the dispersed character of knowledge, and on the consequent coordination problem. (This does not mean that Mises's seminal insights in each of the above two areas cannot be faithfully articulated in plan-coordination terms; it merely means that Mises himself never explicitly recognized this possible articulation.)."
} 
the entire path in retrospect. The variations here give rise to different versions of the claims under rubric II, and we shall see that the versions have differing implications.

Rubric III: Here is a Kirznerian coordination wherein every entrepreneurial discovery is coordinative.

Table 2: Kirzner has projected III onto Hayek by attributing II to Hayek and equating II and III.

\begin{tabular}{|c|c|c|}
\hline $\begin{array}{c}\text { I } \\
\text { Concatenate } \\
\text { coordination }\end{array}$ & $\begin{array}{c}\text { II } \\
\text { A notion of } \\
\text { fulfillment or } \\
\text { compatibility }\end{array}$ & $\begin{array}{c}\text { III } \\
\text { A notion of } \\
\text { opportunity- } \\
\text { exploitation }\end{array}$ \\
\hline $\begin{array}{l}\text { Hayek's (and } \\
\text { Mises's) } \\
\text { statements } \\
\text { about } \\
\text { coordination. }\end{array}$ & $\begin{array}{l}\text { Kirzner holds that } \\
\text { coordinative actions } \\
\text { necessarily entail the } \\
\text { resolution of } \\
\text { problems in } \\
\text { fulfillment or } \\
\text { compatibility of plans } \\
\text { or expectations (or } \\
\text { the correction of } \\
\text { error). }\end{array}$ & $\begin{array}{l}\text { Kirzner holds that } \\
\text { every entrepreneurial } \\
\text { gain is coordinative. }\end{array}$ \\
\hline
\end{tabular}

Kirzner projects III backwards onto Hayek (and Mises), first, by attributing II to Hayek's meaning of coordination, and, second, by equating II and III. We feel that both steps are unacceptable.

\section{E. Kirzner's Invocation of Hayek}

Hayek wrote a few passages about expectations or plans being fulfilled, realized, or mutually compatible. In every such instance, however, he was speaking of either equilibrium or order, not coordination. In 1937, Hayek wrote: "For a society, then, we can speak of a state of equilibrium at a point of time - but it means only that the different plans which the individuals composing it have made for action in time are mutually compatible" (Hayek, 1937, p.41). Perhaps one may read Nash equilibrium into Hayek's idea of equilibrium. Hayek later (1978c, p.184) says he prefers the term "order" to "equilibrium," and in trying to clarify "order" he writes of plans being realized or expectations being correct (1973, p.36, p.44-55, 
p.103, p.106f). ${ }^{8}$ The important thing about these passages is that "coordination" is nowhere to be found. Hayek never equates equilibrium and coordination, and never defines or characterizes coordination in terms of plan/expectation fulfillment or compatibility.

Indeed, in "Economics and Knowledge" (1937, p.58), Hayek first writes of equilibrium and then emphasizes that such a position of equilibrium "is not an equilibrium in the special sense in which equilibrium is regarded as a sort of social optimum" - this special sense being coordination, though he does not use the word. Thereafter in the article, Hayek talks in a way highly reminiscent of his 1933 lecture. He speaks of a "social mind" (p.54) that sees opportunities unknown to actors in the position of equilibrium. In no way does Hayek affirm usage of the term "equilibrium" for the "social mind" concept. Hayek's primary point is that "equilibrium analysis can really tell us nothing about the significance of such changes in knowledge" (p.55). Thus, Hayek's point is that important coordination claims cannot be derived solely from "the pure logic of choice." Decades later, Hayek (1983) said he wrote the piece "to persuade my great friend and master, Ludwig von Mises, why I couldn't accept all of his teachings."

It is clear that Hayek used coordination with a connotation of economic goodness. Kirzner concedes that "at least sometimes" Hayek used coordination to mean "some desired overall patterned outcome" (2000, p.189). Referring to Klein (1997a), 9 Kirzner concedes (p.199) that such usage in Hayek conforms to Klein's idea of concatenate coordination, and Kirzner himself provides several excellent Hayek quotations in which coordination means concatenate coordination. Kirzner concedes that these occurrences of coordination do not coincide with his own notion of coordination: "such coordination is certainly not defined in terms of the mutual compatibility of independently made plans or independently held expectations" (p.189).

\footnotetext{
8 In Hayek's order, plans "can be mostly realized" (1978c, p.184; emphasis added) and that expectations "have a good chance of proving correct" (1973, p.36; emphasis added), showing philosophical departure from the categorical approach of Mises.

${ }^{9}$ Kirzner refers to Klein (1997a), where concatenate coordination was originally and regrettably dubbed by Klein as "metacoordination." That regrettable term also appears in Klein (1998).
} 
Kirzner then insists "that, at least part of the time, Hayek was using the term 'coordination' not in the sense of Klein's [concatenate] coordination, but in the sense of the achievement of mutual compatibility among independently-made individual plans (without regard to any overall desirability of this outcome)" (2000, p.199). But the evidence is thin. At the top of page 191, Kirzner quotes two essays by Hayek, but the quotations by no means clearly involve Kirzner's notion that coordination hinges on plan/expectation fulfillment or compatibility. In one quoted passage, Hayek says that in a decentralized system "some method must be found for coordinating these separate plans which does not depend on conscious central control" (Hayek, 1941, p.144). The grand concatenation of course entails individuals' plans, and of course a good concatenation must entail good coordination of such plans. The other quotation has Hayek speaking of a decentralized system "with prices conveying to each the information which helps him to bring his actions in relation to others" (Hayek, 1939, p.194). The phrase is brief and "in relation to others" is vague, but it is appropriate to read the "helps him" in the following allegorical invisible-hand sort of way: Free prices conduce to individual actions corresponding in a rough way to the actions that individuals would take if they were cooperating in the commonly valued project of making a good overall concatenation. Thus, the "helps him" is allegorical - prices help individuals do their part in the imagined cooperation. Hayek is contrasting the effectiveness of the decentralized approach to that of central direction which, in the very next sentence, is said to entail the construct of "some individual mind." Hayek is yet again grappling with the problem of his 1933 lecture, where he affirmed the need to speak of some such "sense" of the social "organism" even in argumentation against central control. ${ }^{10}$ The passages that Kirzner invokes are but further instances of Hayek speaking of concatenate coordination.

\footnotetext{
${ }^{10}$ Further, note that talk of prices "conveying" or "communicating" information as Hayek famously writes elsewhere - also is metaphorical or allegorical. Literally speaking, the only information communicated by a price is how much money it will take to get the seller to sell. There is no literal communication about relative scarcities, profit opportunities, and the like. But again, in the allegory implicit in Hayek, the communication of such things would correspond in a rough way to the inducements arising from prices.
} 
Similar interpretation should be applied to the single occurrence of the term dovetail in Hayek's Individualism and Economic Order. We enter into consideration of "dovetail" because Kirzner and his followers have used this somewhat mysterious term to signify the distinctive Kirznerian notion that coordination hinges on plan fulfillment/compatibility. As noted, Kirzner (2000, p.190) says that "the dovetailing of individual purposive efforts" is the "earmark" of such coordination. Let us examine Hayek's employment of "dovetail," which occurs in the essay "The Use of Knowledge in Society" as the essay appears in Individualism and Economic Order. ${ }^{11}$

Which of these systems is likely to be more efficient depends mainly on the question under which of them we can expect that fuller use will be made of the existing knowledge. This, in turn, depends on whether we are more likely to succeed in putting at the disposal of a single central authority all the knowledge which ought to be used but which is initially dispersed among many different individuals, or in conveying to the individuals such additional knowledge as they need in order to enable them to dovetail their plans with those of others. (Hayek, 1948, p.79; emphasis added)

Once again, we see Hayek's main concern as concatenate coordination, and we would interpret "enable them to dovetail their plans with those of others" as describing the allegorical need to guide individual efforts in ways that improve the concatenation. Hayek is considering which system is "more efficient," and how "fuller use" may be made of knowledge. A dove's tail serves as metaphor for concatenate coordination: Feathers intermesh so as to produce the curves of the tail; it consists of minute individual protrusions, and, like other spontaneous orders in nature such as crystals and snowflakes, is beautiful or pleasing to a mind imagined to behold it. The individual feathers do not have plans and hence do not experience plan fulfillment. At the same time, we recognize that "dovetail" does carry a connotation that, in their situations, individuals experience a kind of plan fulfillment and mutual (or Schelling) coordination with their partners. But that connotation does

${ }^{11}$ We notice that as originally published in the American Economic Review in 1945, Hayek used "fit" in lieu of "dovetail." 
not detract from the larger concatenate-coordination interpretation, for one core value of the moral community of which Hayek is participating in is that individuals should normally experience a sense of purpose, fulfillment, and local cooperation (or mutual coordination) in their lives.

Kirzner (2000, p.191) next tries to show that Hayek is Kirznerian by providing two quotations in which Hayek writes of plan/expectation fulfillment or compatibility, but in those passages Hayek is speaking of equilibrium, not coordination. In fact, the two papers that Kirzner quotes, namely Hayek 1937 and 1939, contain no occurrence of the term coordination or its cognates. ${ }^{12}$

The only proper location of Hayek in Figure 2 is under rubric I, concatenate coordination. Kirzner locates him "at least part of the time" under rubric II. Then, in equating II and III, Kirzner implies that Hayek is therefore with him under rubric III. Now we turn to the problems of equating II and III.

\section{The Disparities between Kirzner's Two Pieces}

As we have seen, Kirzner makes strong claims about coordination in relation to plan fulfillment/compatibility and in relation to the discovery of opportunities. These are represented in Figure 2 as rubrics II and III. To maintain his categorical system, these two pieces must fit neatly together. Here we argue that those two pieces do not fit neatly together. Our own understanding leaves open the distinct possibility that weakened versions of the claims may be vitally important, as elaborations on concatenate coordination, but we think that the categorical versions should be jettisoned.

A. Entrepreneurial Discovery Need Not Entail Any Experience of Correction (or, III Does Not Imply an Error Version of II)

\footnotetext{
12 Similarly, elsewhere Kirzner (2000, p.79) writes of how Austrian economics "has dismissed the idea that the function of the market is to allocate resources efficiently" and instead embraces the idea that the function of the market is "one of coordinating the plans" of participants, and then says how this coordinative function "has been interpreted as that of promoting" discovery, and cites, aside from his own work, Hayek's "Competition as a Discovery Procedure" (1978c). The term coordination, however, does not occur in Hayek's piece.
} 
Kirzner (1985, p.52) writes: “To act entrepreneurially is to identify situations overlooked until now because of error."13 In addition, Kirzner holds that error necessarily entails disappointment and/or regret: "The entrepreneurial-competitive process becomes visible...as discovering and correcting discordant individual plans and decisions" (1973, p.218). Our objection can be couched within an example offered by Kirzner (1979, p.161). Robinson Crusoe stands on shore catching fish day after day. One day he realizes that he could better catch fish by making a boat. Kirzner writes: "Nothing has changed since yesterday except that Crusoe has discovered that his time is more valuably spent in building the boat than in catching fish. He has discovered that he had placed an incorrectly low value on his time. His reallocation of his labor time from fishing to boatbuilding is an entrepreneurial decision, and, assuming his decision to be a correct one, yields pure profit in the form of the additional value discovered to be forthcoming from the labor time applied." In this story, does Crusoe necessarily experience feelings of disappointment or regret? In our view, it is possible that he would experience regret in not having come to the boat-method sooner. Kirzner says that Crusoe "has discovered that he had placed an incorrectly low value on his time." That telling suggests regret; it suggests that Crusoe feels that he had erred in not previously seeing the boat-method opportunity. But with a slight change in the story we may have Crusoe entrepreneurially discovering the boat-method opportunity without any such feeling of regret - indeed, the term "entrepreneurship" would seem to suggest an insight that was not obvious. At any rate, it is perfectly natural to have Crusoe one day seeing the boat-method without his experiencing any sense of previous error, feeling neither regret nor disappointment. Indeed, if Kirzner maintains that every entrepreneurial discovery implies preceding error and hence disappointment and/or regret, then humanity must be a lugubrious lot, for they often look back on their preceding actions with a better interpretation of the information they had had. By making his claims categorical, Kirzner boxes himself into identifying error (and hence disappointment and/or regret) in any previous action that one would revise based on one's later

\footnotetext{
13 Similarly: "The opportunities that market entrepreneurs perceive and exploit are created by earlier coordination failures by market participants" (Kirzner, 1992b, p.91).
} 
interpretation of the information. But such talk will often simply do violence to our language. One day a light bulb - illuminating how he may fashion a boat - goes off in Crusoe's head. This entrepreneurial moment is, quite plausibly, one of gleeful pride. Crusoe does looks back on yesterday with neither disappointment nor regret; rather, today he feels a sense of improvement and forwardness. Entrepreneurship does not necessarily entail preceding error or any sense of disappointment or regret. As for the coordinative aspect of the story, it is natural enough to say that Crusoe's discovery is coordinative, for a mind imagined to behold the potentialities would smile on Crusoe's advancement. That mind would see a better concatenation of resources and efforts in Crusoe's world. The story is one of coordinative entrepreneurial discovery, but Kirzner's strict coordination claim involving error, disappointment, or regret must be dropped.

It is straightforward to take the point beyond Crusoe to the normal economy. Entrepreneurial actions in the economy simply need not entail any disappointment or regret about preceding actions. A story of entrepreneurial discovery is Somerset Maugham's verger who, unable to satisfy his urge for a smoke, is struck by the notion of opening a tobacco shop in the lacking area. In Maugham's story, the verger feels neither disappointment nor regret in not having come to the idea earlier, nor does anyone else. There is no reason to insist, as does Kirzner, that there was any prior error. If in Kirzner's system entrepreneurial discovery necessarily entails "correcting discordant individual plans and decisions" (1973, p.218), then there is something very wrong with the system. If prior to the verger's discovery some being had a feeling of discord, that being could only be an imaginary one who beholds the potentialities - and Kirzner says that is not what he means.

\section{B. Entrepreneurial Discovery Often Upsets Other People's Plans} (or, III Does Not Imply a Fulfillment Version of II)

By all intuitive accounts, entrepreneurial discovery often upsets people's plans. Entrepreneurs often surprise established businesses, upset customs, and frustrate some customers. Had the entrepreneurial discovery not occurred, those customs and businesses would have gone forward as planned - actual expectations would have been fulfilled. 
Kirzner notes (2000, p.142, p.250) that he has received this objection many times. Kirzner deals with the objection by saying that the plans and expectations held by the other businesses and their customers were erroneous all along - that they did not correctly take into account the realities of the situation. It will be useful to scrutinize Kirzner's discourse on this matter.

In a subsection called "Entrepreneurial Innovation Coordinative or Disruptive?" (2000, p.249-252), Kirzner takes up the challenge:

To see why and how I believe it is possible and accurate to insist on my use of the term 'coordinative' to describe the entrepreneur's behavior, it will be useful to focus on an example of bold, creative, innovative Schumpeterian entrepreneurship responsible for a dramatic technological breakthrough, revolutionizing an entire industry. (p.250)

Notice that Kirzner promises an example of "the entrepreneur's behavior" - in the singular - but in the ensuing pages we never find such an example. The next sentence reads: "Consider the invention and innovation of the automobile in the U.S." He elaborates on the example, but henceforth, at least four times, it is now "entrepreneurs" - plural - who wrought the changes. Rather than the unique action of one individual, several entrepreneurs have come up with the same discovery and are simultaneously carrying it out or are poised to carry it out. In this story, no single entrepreneur really upsets the plans of the buggy-makers, because if entrepreneur A fails to make the discovery, the buggy-makers' plans will be devastated just as thoroughly and just as swiftly by B, C, D, and E. Thus Kirzner writes: "The truth, as we now know, is that it was an industry sitting on a powder keg waiting to explode" (p.251). Thus, Kirzner has shifted from "the entrepreneur" to an example that does not face up to the challenge. Suppose there is one pioneering entrepreneur without like in sight. If we compare the world with and without that entrepreneur's discovery, we see that without his discovery some buggy makers will go on better, their plans will be fulfilled, at least for a longer stretch. Dealing with the buggy-makers' disappointment and incompatibility that does result from the entrepreneurial discovery, then, must lead Kirzner into issues of aggregation. 
Another notable instance of Kirzner attempting to address the same challenge is in Kirzner (2000, p.142f), where he answers Klein (1997a). Again, we fail to see Kirzner zeroing in on the comparison of worlds with and without a particular entrepreneurial discovery. Again, human experience - verstehen - is not to be credited: "The apparent earlier calm which, as a result of the aggressive new competition, has been followed by sudden disruption, was in fact utterly misleading. That calm was a façade ...” (p.143). In sketching the example, Kirzner does not make explicit an assumption about multiple simultaneous entrepreneurs; instead, this example carries an implicit assumption that the incumbents who foolishly thought they were experiencing calm actually themselves had access to the opportunities in question, and could have taken them into account. Under that assumption, Kirzner is interpreting his claims under rubric II strictly in the "takes into account" version, and not at all in the fulfillment/compatibility version - the distinction again based on how things go along a chosen plan and retrospection regarding the chosen path. Thus we find Kirzner shifting from one version of II to another so as to sustain the various pieces, as though the versions of II all cohere as one. At any rate, one should once again insist: If we stick to the original simple example, in which the opportunity exists for only a single potential entrepreneur, then we must see that some disappointment or upset comes only in the entrepreneurial event. In judging it to be coordinative nonetheless, Kirzner must be engaging in some kind of aggregation - which he denies - or not really invoking rubric II in any fundamental way at all.

\section{Fulfillment and Compatibility Need Not Imply No Further Profit \\ Opportunities (or, a Fulfillment Version of II Does Not Imply III)}

Here we deal with the fulfillment/compatibility version of the claims under rubric II. We contend that the fulfillment and compatibility of plans and expectations do not imply that there are no betterment opportunities out there. A network of people may carry on spontaneously, each making plans and forming expectations about the doings of the others, and they may find their plans and expectations to be fulfilled and mutually compatible in every reasonable and intuitive sense, and yet they may be overlooking opportunities for both individual and social betterment. There may be an opportunity for a better mousetrap out there, but the overlooking of that opportunity by everyone does not necessarily 
involve any upset to their plans or expectations. When the discovery occurs, people might make their future plans accordingly, but there is no necessary implication that their plans up to or at such time go unfulfilled or encounter incompatibilities.

Presumably, that is why, within this rubric, Kirzner at times couches the condition in terms of taking things into account, as when he characterizes coordination as entailing that one "correctly takes into account" how things would go for oneself "were one's own actions to be different" (2000, p.136). If one had, instead, built that better mousetrap (and by implication, we are to suppose, in the first instance discovered the opportunity), then things would have gone better for him. So Kirzner's "takes into account" can do the work necessary to get II to imply III, but fulfillment and mutual compatibility, by themselves, do not deliver that result.

We now replay the point in the contrapositive - that is, we examine the Kirznerian notion that not-III implies not-II: Does the non-existence of a betterment opportunity imply that people do not feel disappointment, discord, or regret? Here we must make use of our earlier distinction between how things go along a chosen path and retrospection regarding the chosen path. The non-existence of a betterment opportunity does imply that people do not feel retrospective regret about the chosen path (assuming of course that they do not come to new spurious notions about what opportunities had existed). As we understand the terms, regret goes with error, and the non-existence of a betterment opportunity implies no error. However, the non-existence of a betterment opportunity does not imply that people do not feel disappointment or discord. That is, things might not go as hoped or expected, even though there was no particularly better way to go about things. It was only the sentiments and expectations that were faulty, not the decisions or actions.

We believe that, all within rubric II, Kirzner has mixed together the two different sets of sentiments about a plan: fulfillment vs. retrospective affirmation. Hayek's words about equilibrium and order - which Kirzner treats as words about coordination - involve fulfillment and compatibility (or, in the negation, disappointment and incompatibility). As Kirzner wishes to claim Hayek as his own, Kirzner uses fulfillment and compatibility, but Kirzner seems to sense that what really does go with his discovery ideas (rubric III) is, 
rather, "taking into account" (or, in the negation, regret). It is only that version of II that implies III. ${ }^{14}$

\section{Problems in Seeing Kirzner's Two Ideas as Characterizations of Coordination}

The previous section considered the Kirznerian ideas of II and III in Table 2. That consideration was primarily immanent criticism of the purported cohesion between those pieces, not criticism of those ideas as necessary characterizations of coordination. Now we focus on the characterizations of coordination in those terms.

\section{A. Problems in Fulfillment, Etc., as Characterization of Coordination}

Kirzner (1992a, p.141-43) develops a traffic signaling system example to explicate coordination. The example proceeds from the point of view of the traffic engineer, not any of the motorists. Kirzner speaks without reservation of programming the system "to control the flow of traffic in some optimal manner" (p.141) to avoid collisions and delays. The purpose to which Kirzner puts the example is to distinguish between the coordination achieved by a static signal program and that achieved by an adaptive signal program that changes based on the history of traffic patterns. This is all well and good - Kirzner at his best. We say that in both aspects, the coordination of which Kirzner speaks is naturally interpreted as concatenate coordination.

Now, suppose the signal program was quite bad - by standards relevant to those likely to be talking in a concerned way about such things. Following Kirzner: "Southbound drivers find themselves waiting at red lights, let us say at 3:00 in the afternoon, for several minutes during which no traffic flows at all in the east-west directions. Clearly this waiting is unnecessary; it means that north-

\footnotetext{
${ }^{14}$ To carry through on the scheme here, we note that III does not imply that (or any other version) of II. That is, as we have already argued, entrepreneurial discovery does not imply disappointment, incompatibility, or regret. The reason we see the relation (that is, the relation between the "takes into account" version of II and III) as only one-way is that we have narrower conceptions of what constitutes an entrepreneurial discovery and what constitutes an error, with the narrowness being a matter of how obvious the opportunity is (or was) - with obviousness understood within and depending upon the context of the discourse. Following Klein (1999), entrepreneurial discovery is only the discovery of non-obvious opportunities, and error is only the non-discovery of obvious opportunities. Thus, entrepreneurial discoveries do not imply previous errors.
} 
south drivers are compelled to act in a fashion that is not coordinated with the decisions of the east-west drivers" (p.141-42). Our point is this: Where, in this sorry concatenation, is there any necessary disappointment, incompatibility, or regret in plans or expectations? Suppose that motorists are familiar with the system. They get into their cars expecting a dreary journey with long delays; their plans and expectations are fulfilled. Moreover, they have no opportunity to improve their situation. There is no sense of regret, nor any feeling of discord or incompatibility with the plans of other motorists.

In this example - which both Kirzner and we readily identify as discoordination - if there is any sense of disappointment, incompatibility, or regret, it must be on the part of the traffic control chiefs. But again there is no guarantee that such persons actually feel any disappointment, incompatibility, or regret. We would hope they care enough about motorists' delays that they come to such sentiments, and we would hope that reform of the system is viable, but, even if not, we may still describe the situation as poor coordination. It is natural to us to think about the satisfaction that a benevolent mind would feel in the achieving of a better signaling system. As for our description of the concatenation as a "sorry" one, we may say that if the benevolent being in fact guided the traffic officials so as to produce the observed system, that being would feel regret over the guidance it issued, a regret that derives in some aggregate manner from its sympathies with the motorists.

The previous examples of Crusoe and of the verger do not necessarily imply any disappointment, incompatibility, or regret. Likewise, people might experience disappointment and discord without there being any discoordination in decisions and actions.

The Kirznerian rubric II involves sentiments and expectations. In our view, the only part to be retained in a significant way is to associate regret or self-reproach with error ${ }^{15}$ - an association that Kirzner strongly affirms sometimes (Kirzner, 1979, p.128-130, p.146, p.147; 1985, p.56; 1994, p.224-25). As for the other sentimental and expectational aspects of Kirzner's discourse about coordination - the positive notions of fulfillment and compatibility, the negative notions

15 In the matter of associating regret/self-reproach with agent error, we would allow the element of regret to be merely potential or vicarious. In the matter of associating regret/self-reproach with social error, we project the semantics of agent error onto beings that might be only fictitious, metaphorical, or allegorical. 
of disappointment, incompatibility, and discord - we see them as only very loosely related to coordination. The problem is that our actions involve hopes, visions, and vague awareness of possible contingencies. Often, our doings are better described as "muddling through." There is often ambiguity about whether "our plans" go as expected. They rarely go as well as we wish, and they almost never go in a way that is utterly surprising, and how we describe the experience might depend on the discourse situation. Further, suppose that people learn to expect little. Does fulfillment or disappointment depend on the dispositions or personalities of the individuals involved? While we accept discovery as highly consonant with concatenate coordination, we do not have the same view of fulfillment and compatibility. ${ }^{16}$

\section{B. Problems in Claiming that Every Entrepreneurial Action Is Coordinative: "All Swans Are White"}

One can make a system in which all swans are white by defining certain non-white birds as non-swans. In managing the "field of force" of our scholarly discourse (Quine, 1961), we jointly manage the strength of claims (the minimal percentage of swans that are white) and the semantic distinctions so as to achieve reasonable consistency. But consistency is not our only objective. Not all consistent systems are equally good. We have to consider the value or usefulness of an entire field, one against another (Quine, 1961). If you make your claims 100 percent, you have a much more complicated and possibly eccentric - set of distinctions. You might have to attend to definitional "redistricting" in myriad minute instances to protect your 100 percent. Consider the opposite extreme. Suppose you work with 0 percent statements: "Swans are white zero or more percent of the time," "Swans have feathers zero or more percent of the time," and so forth. Then, for consistency, you don't have to worry about your distinctions at all; even bananas may be counted as swans. But 0

\footnotetext{
${ }^{16}$ Perhaps these terms have gotten into the swirl because of the extensive Austrian discourse involving equilibrium and its cognates. Austrians have a practice of speaking of "equilibrium," etc., without reference to a model. To our mind, "equilibrium" and its cognates are tropes that only have meaning within certain genres of metaphor or storytelling involving a model. The speaker chooses model metaphors to serve the purposes of the discourse. Whether some particular phenomena are to be described as equilibrium or disequilibrium depends on the model employed.
} 
percent claims aren't serviceable. In managing this Quinean problem, we adjust at both ends, finding percentages for our claims in light of the practicality and meaningfulness of the semantic options. Like Mises and Rothbard, Kirzner holds an image of science that makes him enamored of 100 percent claims. As a concomitant, we contend, he ends up making impractical distinctions. Adam Smith was much more attuned to the Quinean problem, much less enamored of 100 percent - even suspicious of it - and more respectful of semantics "plain and intelligible to common understandings" (Smith, 1776, p.687).

Kirzner says that 100 percent of successful entrepreneurial actions are coordinative. We say it is less than 100 percent, but high enough to give the claim presumptive truth. It seems to us that many kinds of counter-examples can be creditably presented. There are surely cases in which a first mover into a market space happens to be below average, and that things would have gone better if the first mover had not moved into the space and gummed it up. This firstmover problem crops up with regard to product lines, conventions, standards, internal procedures, relationships, etc. Many other kinds of examples might be given in which entrepreneurial gain is discoordinative, including monopolistic situations, speculative situations, misleading advertising, exploitation of ignorance (e.g., tourist traps), shirking and laziness, opportunism, exploitation of a commons, businesses that are obnoxious or distasteful to some of the local community, and demerit markets. Ricketts (1992, p.77-78) offers the example of a putative entrepreneur getting his acquaintances drunk and talking them into a deal that they'll later regret. He also speaks (p.82) of interloping entrepreneurs undoing beneficial long-term practices. All of these can be voluntary, profitable, and frowned on by the moral community involved in our coordination talk. While the proper presumption is that voluntary successful entrepreneurship is coordinative, there is no basis for insisting that it always is. ${ }^{17}$ When Kirzner attempts to deal with some of these challenges, he leaves us unsatisfied.

17 George Selgin (1983, p.39) distinguished between "equilibrating" and "coordinating," and challenged Kirzner on the claim that entrepreneurial action is necessarily coordinating. At one point (p.39) Selgin associates coordination with "increased well-being." 


\section{C. $W$ as The Communist Manifesto Coordinative?}

In a moment of entrepreneurship, a man discovers an opportunity to write a certain book, get it published, and sell many copies. He enlists a collaborator and voluntarily agrees with publishers to produce the book, who voluntarily sell it to "sovereign" consumers. The book is very popular. Gains are made by the entrepreneur and his associates. Their plans and expectations are fulfilled. They have no regrets.

The author is Karl Marx, and the book is The Communist Manifesto. On Kirzner's view, it seems, one would have to say that the entrepreneurial act was coordinative. It would seem to satisfy all of his diverse aspects of coordination. In our view, however, it is reasonable for those who regard The Communist Manifesto as pernicious to judge this entrepreneurial act discoordinative. To a liberal humane mind imagined to behold the vast concatenation and its potentialities, the creation of The Communist Manifesto is a sad and lamentable day. Even if we set aside the pernicious effects the book has had on coercive policymaking, the cultural effects were unfortunate.

Kirzner would, no doubt, say that Marx's writings are filled with errors. But one would have a hard time interpreting the acts involved as error in Kirzner's economic sense. Marx gained, his associates gained, the activity was voluntary, and nothing was regretted. To our way of thinking, Marx's errors were not agent errors, but were errors only in the allegorical sense exposited earlier when discussing the traffic signal system: If the imaginary benevolent being in fact guided Marx and Engels to produce The Communist Manifesto, that being would feel regret over the guidance it issued. Even though there is no agent error, there can be error in terms of the "sense" of the social "organism" of which Hayek (1933a) spoke. Voluntary, successful entrepreneurial developments are sometimes discoordinative.

The Communist Manifesto is merely an extreme example of something that frequently occurs in cultural markets - the prosperity of unfortunate, discoordinative ideas, forms, beliefs, and sentiments. Even if we presuppose that coercion plays no role - that is, we assume that the cultural markets are perfectly free, and that there is no hazard of the cultural wares inciting coercive actions - it still makes sense to suppose that sometimes discoordinative activities will prosper. We may have good reason to believe that the very discoordinativeness of activities in such a setting gives rise to forces that tend to make the activities in question unprofitable, but there is 
no reason to suppose that such an invisible hand works instantaneously, which means that along the way it is likely that many agents will reap entrepreneurial gains from discoordinative actions.

\section{D. "Markets" vs. "Institutions"}

How would Kirzner deal with such contentions about cultural products? A clue might be found in his discussion of pathdependence. Kirzner (1992a, p.166-179) confronts the possibility of inferior patterns, standards, and practices getting locked in. Kirzner even uses "inferior" and "superior" to describe them. He gives the example of using feet and inches, and notes that "a superior system of measurement might have emerged" (p.172). He gives the example of "some hardy soul" (p.175) starting a path in a deep snow, and others following in this footsteps. He suggests that the path might persist through time as the route people follow even though it is very inferior to other routes that might have emerged. Kirzner seems to be acknowledging that, under the circumstances, successful entrepreneurial action by certain path-finders can produce inferior results. But he safeguards his categorical claims by saying that such cases concern "institutions," whereas his theories are about "markets." In the paragraph that concludes the essay, Kirzner writes:

...these earlier economic insights into the spontaneously coordinative properties of markets do not, in themselves, provide any reassurance concerning the benign quality of the long-run tendencies of institutional development....the spontaneous co-ordination which occurs in markets provides us with no basis for any extension of the welfare theorems relating to markets to the broader field of the theory of institutional evolution. (1992a, p.179)

Kirzner draws a line between "markets" and voluntary "institutions." But how does one draw the line? Will one say that any time there is any element of path-dependence - in products, in standards, in practices, in customs - the activity becomes "institutional" and hence cannot be taken as a challenge to his theory? But don't practices and customs suffuse all market activity? A barbershop, a grocery store, Craigslist.org, Amazon.com, etc. are, in every sense of the term, institutions. The expressions and workings of demand and supply typically proceed within the context of 
institutions. One might wonder whether Kirzner's "market" represents merely some blackboard example devoid of institutional context. Yet, Kirzner goes about his categorical coordination claims as though they have common relevance to real-world economic affairs. Where he separates "markets" and "institutions" Kirzner (1992a, p.166-179) offers no clarification of the difficulties in making that separation - he does not even acknowledge the difficulties.

Moreover, Kirzner's "inferior" and "superior" in speaking of "institutions" is quite mysterious. In speaking of "institutions," Kirzner avoids the term coordination, apparently because he wishes to reserve the coordination criterion for talk of markets. So what is the criterion for institutions? The only clarification is reference to Pareto rankings (p.170, p.172). But that is so narrow as to be useless indeed, shouldn't we assume that the first hardy soul who trudged through the snow did so in a way that was individually optimal? Kirzner speaks of "inferior" and "superior" without any indication of the criterion involved, or of how it relates to coordination.

Brian Loasby (1982), Martin Ricketts (1992), and others have brought similar criticisms. Kirzner relates Loasby's challenge: "Loasby stresses not only the possibility of entrepreneurial mistakes in the face of an uncertain future, but also the possibility that entrepreneurs discover profit opportunities through deliberately misleading the consumer (Loasby, 1982, p.121) or through speculatively purchasing assets..." (Kirzner, 1992a, p.13-14). Kirzner sets up the challenge quite dramatically, but in the remaining 13 pages of the essay he never seems to answer it. He essentially addresses a different challenge, namely that sometimes entrepreneurs err and drive the market in a wrong direction (a matter that Loasby also raised). Kirzner writes: "the postulation of a tendency for profit opportunities to generate equilibration has not been put forward as an inexorable, determinate sequence. The emphasis upon the incentive to win profits has not been intended to deny the possibility of entrepreneurial losses" (p.21). His lengthy examples of the erroneous bicycle factor inducing a demand for steel (p.29-30) and of the shoe producer acting through time (p.32f) are examples of entrepreneurial error, not entrepreneurial success. He says at the end of the shoe-producer example: "But it is always the case, nonetheless, that appropriate entrepreneurial incentives do, at any given moment, offer themselves in regard to the path relevant to the realities" (p.31). But the issue is whether entrepreneurial incentives not thusly 
appropriate, too, might ever offer themselves, and Kirzner never seems to address the matter. He concludes the essay with many gestures at concession and relaxation of his claims (see esp. p.34-36), but without confronting the real challenge. Similarly, in responding to Ricketts' point that sometimes profit can be had in ways that are indubitably voluntary but manipulative, Kirzner (1992b, p.93) dodges it with the pronouncement that his work is not intended to apply in contexts " $[\mathrm{w}]$ here property rights are not well defined, not fully protected, or otherwise not complete enough to satisfy the conditions for a fully private enterprise economy."

\section{E. Does Kirzner Stretch "Entrepreneurship” to Include All Action?}

We suggest examples of discoordinative successful voluntary entrepreneurship, including:

- Misleading marketing practices, manipulation

- A low-quality first mover leading to lock-in

- Speculative bubble

- The Communist Manifesto

- Establishing an opium den in a community

- Local cultural effects (e.g., a brothel, obnoxious billboards)

- Opportunism, shirking, etc.

One way Kirzner might try to deal with some of these examples is to regard all action as entrepreneurial and thereby to disqualify some of the examples as cases of omnilateral successful entrepreneurship. Suppose a tourist trap sells tourist items at terms which, say, we know the consumer is very likely to quickly discover were bad terms. Suppose most such buyers will presently feel "ripped off." 18 Kirzner might say that this is not an example of successful entrepreneurship because the success is not omnilateral - the consumers, too, he might say, are entrepreneurs, and they do not feel the transaction was a success. Mises (1966, p.252) writes: "In any real and living economy every actor is always an entrepreneur," and

\footnotetext{
18 To clarify further, assume that the consumer affirms the level of trust he had put in the merchant's decency. He feels, not that he erred, but that he was "ripped off," although not quite defrauded in a sense that would make what the merchant had done coercive.
} 
Kirzner (1979, p.28) quotes the statement approvingly. ${ }^{19}$ Thus, every consumer who walks into a 7-Eleven and buys a carton of milk instantiates the entrepreneur. We think that this indiscriminate use of "entrepreneur" or "entrepreneurship" is wrongheaded. Interpretive perception plays some role in all human action, but we think that the entrepreneurial aspect corresponds with the non-obviousness of the opportunity discovered. ${ }^{20}$ Following the accustomed grooves of going to 7-Eleven to buy milk usually will not qualify. Rather than seeing a continuum of interpretive perceptiveness and demarcating an exceptional category as entrepreneurial - like Schumpeter (1934, p.81-82), not only for entrepreneurship but for "being able to sing" Kirzner sometimes insists that the "zero" point of interpretive perceptiveness is mechanical and that anything greater than zero is entrepreneurship. It is like treating the idea of "fatness" as having more than zero fat on one's body, or saying that thin people are "a little fat." We believe that this is misguided. We believe that Kirzner conflates entrepreneurship and interpretive perceptiveness, just as the suggested analogy would conflate fatness and body weight. Properly speaking, thin people are not in the "fat" category at all, and people who show little or only ordinary interpretive perceptiveness are not in the "entrepreneur" category at all. ${ }^{21}$

\footnotetext{
${ }^{19}$ See also Kirzner (1973, p.33f) and (2001, p.87).

${ }^{20}$ See Klein, 1999, p.61-62. Klein's approach would focus more on types of discoveries and discovery factors (Klein, 1997b), and would relinquish "entrepreneur" more to ordinary language; this relates to the point by High (1982, p.166) and Ricketts (1992, p.72) that Kirzner's system does not allow a place for entrepreneurial losses. The refocusing of Kirzner's insights on discovery factors, not entrepreneurship, also relates to the reservations that Peter G. Klein (2008) and Salerno (2007) have about Kirzner's characterization of entrepreneurship.

${ }^{21}$ Kirzner's overly expansive conception of entrepreneurship touches another problem we see in Kirzner. We focus on Kirzner's claim that every entrepreneurial event is coordinative. But Kirzner also asserts the converse - that coordinative enhancements come only by entrepreneurial actions. He suggests this when he writes: "What alone tends to introduce a modicum of consistency and coordination into this picture, preventing a situation in which even the slightest degree of coordination could exist only as a matter of sheerest chance, is market entrepreneurship, inspired by the lure [of] pure market profit" (1973, p.59; emphasis added; see also 1992a, p.151). We rejected Kirzner's claim that coordinative enhancements (save those by sheerest chance) come only by entrepreneurial action because we take a narrower view of entrepreneurship. To follow through on our analogy in the text, to say that coordinative enhancements
} 
Indeed, Kirzner seems to be inconsistent in this regard. In keeping with ordinary language, Kirzner writes of entrepreneurial discovery as an "unanticipated enjoyment" that "lifts one out of the routine sequence of everyday experience" (1992b, p.86). In general, one naturally reads Kirzner's entrepreneur talk through the lens of ordinary semantics. Kirzner seems to revert to the overly expansive conception only when he needs to invoke an idea of omnilateral entrepreneurial success to get out of certain binds.

If Kirzner wants to hold that "every actor is always an entrepreneur," where does that leave him? First, his statement about the coordinativeness of activities that satisfy omnilateral successful entrepreneurship has coverage that is significantly truncated. Perhaps Kirzner would say that it simply does not apply to the tourist trap, which he might agree is discoordinative, since the consumers, too, are now counted as entrepreneurs. Could he likewise exclude the several other examples we offer? Perhaps, with enough work, but it seems to us that he will need to get into counterfactuals about collective action (e.g., in the path-dependent cases) as well as whether we may say that people act in the forming of certain attitudes, sentiments, expectations, and habits, and even in adopting certain beliefs: Are we to say that one commits entrepreneurial error in investing intellectual, moral, or spiritual capital in an inferior technological system, The Communist Manifesto, a drug habit, or identification with a "clean" neighborhood? Now that everyone is an entrepreneur, whatever basis we have for saying that an event is discoordinative might be turned by Kirzner into an instance of some entrepreneur not having acted successfully. Thus, once we minutely, idiosyncratically snip away all the discoordinative cases, we are left with only coordinative cases.

It appears that Kirzner goes to impractical lengths to preserve certain Misesian "pure, universal truths of economic theory" (Kirzner, 2001, p.56). But, if this is how Kirzner would handle the challenging cases, he must admit the truncated coverage of the application of those truths. The "pure truths" do not apply universally, except in the sense that they apply universally within the hodgepodge of cases in which they apply. This is unfortunate. The vital truths that Kirzner teaches would, if rendered in by-and-large versions, be more serviceable and more widely applicable. Instead,

come only by entrepreneurial actions is like saying that coordinative enhancement come only by actions by fat people. 
because of problems that comes with 100 percent conceptualizations, people jettison what is vital and good in Kirzner.

\section{F. Is Kirzner Building Out Around an Axiom About Voluntary Interaction?}

What would it mean for Kirzner for entrepreneurship to be discoordinative? Studying Kirzner's works carefully, one gets the feeling that "coordinative" is necessarily built into successful voluntary entrepreneurship - or, more generally, simply successful voluntary action - by Mises's dictum of human action.

Murray Rothbard was much more blatant in building out around an axiom about voluntary interaction. He propounds a principle of "demonstrated preference," minimizes talk of entrepreneurship and coordination, and states bluntly: "Voluntary exchanges, in any given period, will increase the utility of everyone and will therefore maximize social utility" (1962, p.770) as well as that "no government interference with exchanges can ever increase social utility" (1956, p.252). Rothbard makes his claim to 100 percent deduction quite clear: "since all government actions rest on its taxing power, we can deduce that: no act of government whatever can increase social utility" (1956, p.252). Similarly, Joseph Salerno (1993, p.131) writes: "We may thus conclude that every act of intervention unambiguously lowers social welfare." Kirzner often seems to be making the same kind of 100 percent claim, but much less explicitly. If so, why not make it explicit? If Kirzner is intent on having a system in which voluntary implies coordinative, why not make that clear from the outset, and then proceed to show how he proposes to alter the entire field of concepts, semantics, and statements so as to achieve that goal? Doing so would have the virtue of directness.

In the essay "The Limits of the Market" (contained in Kirzner, 2000), Kirzner denies the possibility of faulty market operation; he denies the very idea of market failure. But in Kirzner's scheme, what would it mean for the market to be faulty, for there to be market failure? Has he done nothing more than twist coordination talk and its domains as needed so as to maintain that successful voluntary action in the market is always coordinative?

\section{G. Economic Goodness and Some Larger Goodness}

Even if one accepts Kirzner's distinction between "markets" and "institutions," and supposes that there remain substantive cases and issues in the "market" category, do we find Kirzner in that domain 
taking a firm Rothbardian libertarian line? No, we do not. We find out, essentially, that while coordination is the last word in economic goodness, it does not necessarily agree with some larger goodness. In Kirzner's eschewal of the Rothbardian line, we encounter another distinction:

To say that the market process works successfully in the context of externalities is certainly not to pronounce the market outcome socially optimal... Nor is it, in and of itself, to declare governmental attempts compulsorily to internalize externalities, to be a definite error (since, after all, governmental policy may seek to reflect citizens' preferences as these are understood in moral or political terms, rather than in the narrow, austerely 'scientific' terms within which economic science is confined). (Kirzner, 2000, p.82)

Kirzner seems to be saying that his coordination claims pertain only to "economic" aspects of preferences, plans, expectations, opportunities, etc., as opposed to "moral and political" aspects. In the essay, Kirzner is not dealing with issues like culture or political identity but with conventional discussion of economic externalities such as pollution. Kirzner seems to be saying that it may be socially bad if gas stations sell leaded gasoline and make profits, but the external ill effects do not count in considerations of whether selling leaded gasoline is coordinative. Somehow those ill effects are cast out as "moral and political."

There might be merit in distinguishing "economic goodness" from other kinds of goodness - notably some larger goodness that subsumes economic goodness. But Kirzner seems to make the distinction simply to maintain his 100 percent claims while eschewing the Rothbardian line about larger goodness. If we are serious about a distinction between economic goodness and larger goodness, we should get specific about: (1) what constitutes the distinction, (2) what, broadly, is the nature of larger goodness, and (3) what value the distinction has. Kirzner enters into nothing of the kind.

\section{Can the Coordination Standard Be Used to Criticize Interventions?}

Kirzner's works, efforts, and intellectual community are imbued with liberal purpose. The great message is that liberty is far more 
valuable and worthy than accorded by the public culture and public policy. The teachings on coordination are directly and deeply related to this great message. Kirzner indicates this deep connection when he writes:

We can now understand how Mises came to believe that economic science leads us ineluctably to the conclusion that a policy favoring unfettered free markets, a policy of laissezfaire, of capitalism without any government intervention, is scientifically demonstrated to be the best policy. A free market works in a systematic way to encourage coordination among the decisions of market participants, with the motivating force being the needs and preferences of consumers. (Kirzner, 2001, p.170)

But, while the liberal character of Austrian discourse is plain, when we get down to specifics in Kirzner's works about the connection between coordination talk and policy argumentation, we encounter problems - and we believe that the problems arise from Kirzner's two basic errors: insisting on 100 percent and not embracing concatenate coordination.

\section{A. Kirzner Seems to Say that We Cannot Use Coordination to Compare Policy} Regimes

Despite the liberal flavor of Kirzner's coordination talk, his discourse grows abstruse and inconsistent in attempting to show how the coordination talk works in comparing coordination of policy regimes. He writes: "The criterion is itself admittedly unable to discriminate between the economic goodness of different moral/legal frameworks, unless one of them is taken as the relevant starting point" (2000, p.139). This phrasing (similarly found on p.138) would seem to suggest that you can discriminate between frameworks but that the judgment will depend on which one you start at. A full examination of the texts, however, leaves such a reading in doubt. Another possible reading is that Kirzner is saying you simply cannot make judgments of coordination across legal frameworks.

In attempting to elucidate, Kirzner offers the following:

To see this at the most elementary level, imagine that agent alpha prefers a marginal unit of beef over a marginal unit of 
chicken, while agent beta prefers the chicken over the beef. It will make all the difference in the world, in our judgment of coordination or miscoordination in regard to the distribution of beef and chicken ownership, whether we (i) begin with a situation in which alpha and beta 'own' the chicken and beef respectively, or (ii) begin with a situation in which alpha, say, 'owns' both the beef and the chicken. From the perspective of situation (i), coordination would require that alpha finish up having the beef, and beta having the chicken. But from the perspective of situation (ii), it is that initial situation (in which alpha owns both the beef and the chicken) which is the coordinated situation. From a strictly economic perspective (i.e., from a perspective which is neutral in regard to the relative morality or legality of alternative initial property rights patterns of distribution) one cannot pronounce situation (ii) as economically 'bad' - even though that situation would be perceived as uncoordinated, were our initial vantage point to have been a situation in which the beef and chicken were, initially, differently distributed. (Kirzner, 2000, p.139)

Thus, Kirzner says that if we started with a situation in which alpha and beta each had a piece of meat, but ended with beta having both pieces, the outcome is uncoordinated. Kirzner implies, in parallel fashion, that if we started with beta owning both and ended with each having a piece of meat, it would be uncoordinated. Kirzner does not say how, from each starting point, such outcomes emerge. Kirzner's thrust seems to be that whenever there is an alteration in the "moral/legal framework," then coordination cannot be used. The meat example leaves us uncertain, however, since, in the first example, where Kirzner pronounces the outcome "uncoordinated" it would seem that beta stole alpha's chicken. If that is what Kirzner means to imply, perhaps he would say that individual coercion does not count as an alteration in the moral/legal framework.

Kirzner attempts to clarify by drawing an analogy between the coordination criterion and distance. "The question 'How far is it to Chicago?' cannot be answered except by reference to some 'arbitrarily-given' starting point" (p.139). True enough, but the kind of distance question that would be analogous to the question of comparative coordination is: Which is further from Chicago, St. Louis or Indianapolis? But Kirzner's discussions of these matters 
(principally at 2000, p.80f, p.138f) seem to suggest that there is no comparative coordination across policy regimes. On this reading, we simply cannot speak of whether a policy reform would help or hurt coordination: "coordination cannot be defined except within a given, adopted moral/legal framework; nonetheless, within that framework, it offers an objective criterion" (p.139). To follow through on the distance analogy, Kirzner, then, would be saying that we cannot speak of whether St. Louis or Indianapolis is farther from Chicago.

If Kirzner were to stick to this line, surely it would be quite astonishing. Despite the pervasive liberal character of all the coordination talk, we would be taking Kirzner to be saying that it is useless in comparing regimes. On this view, we cannot say that abolishing slavery was coordinative; we cannot say whether the imposition of pre-market approval for pharmaceuticals was discoordinative; we cannot say that socializing the food industry would be discoordinative. On this view, Kirzner's coordination criterion would say that voluntary entrepreneurial actions within a regime are coordinative, and little else.

\section{B. But Kirzner Uses Coordination to Compare Policy Regimes}

Although Kirzner seems to say that we cannot use coordination to compare policy regimes, he then on the next page (2000, p.140) uses it to compare policy regimes. The sole policy example addressed there is the issue of central planning versus free markets. Again, Kirzner is abstruse, and it is necessary to quote at length:

What Mises showed, of course, was that at a deeper level, the central planner cannot create a true plan, since he cannot engage in 'economic calculation,' i.e., each part of the 'plan' is necessarily made without full awareness of its true implications for other parts of the attempted plan. What this means, in terms of our notion of coordination is that the actions called for by the attempted central plan are uncoordinated in the sense that, were the various agents in the socialized economy to have the freedom to make their own decisions (with full awareness of each other's decisions and potential decisions), (i.e., were they to be assigned specific property rights), they would find it mutually beneficial not to follow the pattern of actions in fact dictated by the central plan - even if the central planner's objective 
was that of fulfilling the preferences of agents, to the greatest socially possible extent. The economic inadequacy of socialist planning is thus to be understood as seen from the hypothetical starting point of some (i.e., any) pattern of property rights. (Kirzner, 2000, p.140-41)

The passage seems to be saying the following: If we assume that the central plan was intended to fulfill "the preferences of agents, to the greatest socially possible extent," and if instead of the socialist regime there was a pervasive assignment of private property rights, then the various agents would have done differently than the erstwhile plan, and on that basis "the actions called for by the attempted central plan are uncoordinated."

Kirzner deems the central plan "uncoordinated" on the basis that, acting under laissez-faire capitalism, "the various agents in the socialized economy... would find it mutually beneficial not to follow the pattern of actions in fact dictated by the central plan." Kirzner does not clarify the principle here, but he seems to be saying that any policy regime that results in outcomes other than those which would prevail under laissez-faire capitalism is uncoordinated. Since any significant departure from laissez-faire capitalism will result in different outcomes, the only thing that such a principle achieves is to render a binary criterion of economic goodness: Laissez-faire private enterprise regimes are coordinated, and all the others are uncoordinated. Such a criterion of economic goodness would be neither useful nor reasonable.

At other moments, Kirzner makes judgments about policy in terms of coordination very plainly. Consider the following two cases:

- "Imposed price ceilings may, similarly, not merely generate discoordination in the markets for existing goods and services (as is of course well recognized in the theory of price controls); they may inhibit the discovery of wholly new opportunities." (Kirzner, 1985, p.38-39)

- "Quite apart from the discoordination generated by such imposed prices in the markets for existing goods and services, price (and also quality) restraints also may well inhibit the discovery of wholly new opportunities" (Kirzner, 1985, p.143). 
Here Kirzner casually cites the "well recognized" problems of price controls as instantiations of discoordination. Such discoordination would surely be a demerit of such regimes, in comparison to regimes without such discoordination.

Kirzner, despite himself, clearly wants to use coordination to judge policy reform. But in a footnote at the conclusion of the primary essay on the matter, he seems to acknowledge that things are unsettled: "We must readily grant that even if the arguments in this chapter are accepted, we have not yet firmly established the usefulness of the coordination concept as the criterion for economic goodness. The serviceability of the coordination criterion, as a device with which to rank a series of alternative policies, has to be concretely demonstrated" (2000, p.147, n18).

\section{On the Evaluation of Price Controls}

Now think about the earlier bulleted statements in which Kirzner says that price controls generate discoordination. How would he square that with his own characterizations of coordination? The "well recognized" disadvantages of rent control involve the deadweight loss from curtailed quantity transacted and the mal-allocation of those units that are transacted. In what way do these problems fit Kirzner's characterizations of coordination? Under rubric II, there is no way to see those problems as either a lack of fulfillment or compatibility of plans or expectations. People expect rent-controlled rates, they expect shortages, queues, and so on. Nor is there any regret on the part of market participants. As for rubric III, the wellrecognized discoordination does not involve any missing of profit opportunities. The law expunges opportunities that would exist in the absence of the law. The standard analysis does not involve any unexploited opportunities. Kirzner has no basis in his characterizations for calling the well-recognized harms of rent control "discoordination."

Indeed, if we were serious about Kirzner's characterizations of coordination, where would that leave the libertarian economist? Quite plausibly, occupational licensing, the postal monopoly, and the government school system tend toward a regimentation of affairs and bring greater fulfillment of plans and expectations. Plans and expectations adapt to any environment, and, thus perhaps there are more moments of frustration and regret in a dynamic system than in a regimented one. Take regimentation to the extreme and think of life 
within a prison or military training camp; in Kirzner's terms of rubrics II and III, these would seem to suffer little discoordination.

The problem is Kirzner's characterization. Of course those interventions are discoordinative, for in the back of our minds is concatenate coordination. To a liberal mind imagined to know the set of possible concatenations, each of those interventions is undesirable relative to freer arrangements. The interventions are viewed as undesirable for a variety of reasons, including matters of discovery, and including standard deadweight-loss analyses.

\section{Why We Should Own Up to - and Properly Locate - the "Loose, Vague, and Indeterminate"}

By 1973, the year of Competition and Entrepreneurship, the economics profession had for many generations experienced the trend toward formalization. Increasingly, human beings were being thought of as optimization machines - a trend exquisitely protested by Buchanan (1979) on moral grounds. On knowledge grounds, Kirzner illuminated crucial ways in which human beings cannot be reduced to machines. The trends against which Kirzner was leaning were part of a broader trend. Modernist social scientists felt the need to do value-free science, to establish separate scientific disciplines, and to schematize the discipline's teachings. These developments went hand-in-hand with the deterioration of any liberal consensus within the moral community - social democracy and interventionism were ascendant and socialism threatened radical change.

While Kirzner's sensitivity to knowledge's richness drew from Hayek, his image of economic science followed Mises. In developing his ideas about entrepreneurship and coordination, Kirzner attempted to preserve the Misesian praxeological vision of wertfreibeit and exact deduction from a priori truths. Kirzner answered one form of modernism with another. He worked hard to have a modernist economic science that incorporated his key insights, but over time the efforts grew increasingly abstruse.

In our view, economics is part of the humanities. It is really political economy, of a piece with moral and political philosophy. Inquiry, argumentation, and judgment in the field is bound to enter into realms of the "loose, vague, and indeterminate," to use Adam Smith's phrase (1790, p.175, p.327). Modernism may be seen as the 
effort to exile the loose, vague, and indeterminate. ${ }^{22}$ The "utility" that agents maximized was utterly vague (Coase, 1977), ${ }^{23}$ but no matter: the substance of "utility" was safely placed outside the province of economic science. All such nebulae were to be eliminated from the science. The aspiration was to make the science a sort of grammar, which Smith described as "precise, accurate, and indispensable" (1790, p.175). But the only way to do this is to skirt the most important things - that is, the most important issues, positions, and arguments. Any economics that speaks to the most important things is, whether it admits it or not, bound to enter into the loose, vague, and indeterminate. Kirzner is devoted to addressing the most important things. He ends up with plenty that is loose, vague, and indeterminate. His discourse includes ambiguities and inconsistencies, such as the following:

- Kirzner runs together two perspectives: Plan fulfillment vs. retrospective plan affirmation. Similarly, he is inconsistent on whether error entails regret. ${ }^{24}$

- Kirzner says that "every actor is always an entrepreneur" (1979, p.28) but also that entrepreneurial discovery "lifts one out of the routine sequence of everyday experience" (1992b, p.86).

- Kirzner says coordination cannot be used to make judgments across regimes, and yet he uses it to make judgments across regimes.

- Kirzner characterizes coordination with the ideas of both rubric II and rubric III, but we have argued that those two rubrics do not go hand-in-hand.

22 Incidentally, it might be proper to see "modern" as post-Newton, and Adam Smith really as something of an exception in the general, centuries-long stream. But modernism becomes especially virulent (and "value free") with the decline of liberalism/rise of social democracy.

23 "To say that people maximize utility tells us nothing about the purposes for which they engage in economic activity and leaves us without any insight into why people do what they do" (Coase, 1977, p.43); "man must recognize that even within his own private sphere of action there is no maximand" (Buchanan, 1979, p.110); "Smith would not have thought it sensible to treat man as a rational utilitymaximiser" (Coase, 1976, p.116).

${ }^{24}$ Again, Kirzner strongly associates regret/self-reproach with error at 1979, p.128130, p.146, p.147; 1985, p.56; 1994, p.224-25. 
Kirzner also makes dubious or vague distinctions, including:

- “markets" vs. "institutions" (1992a, p.166-179)

- "economic" vs. "political" preferences (or aspects/dimensions of preferences) (2000, p.82).

It makes sense that discourse about the most important things would inevitably involve the loose, vague, and indeterminate. If the most important things could be resolved by grammar-like sciences, then those things would be settled and would no longer be most important at the operative margins of discourse. While the aspiration is always to get more of a grammar into our understanding of the most important things, it is vain to think that we can ever elude the loose, vague, and indeterminate.

Owning up to the looseness, we then may think about how best to manage and locate it in our discourse. Our view is that we ought to be open about the looseness of our sensibilities about the desirable, about goodness, and specifically here about the aesthetic aspects of coordination. Kirzner, by contrast, claims to have "a clear-cut, objective criterion" (2000, p.133), with the result that muddleness erupts throughout his teachings.

Mainstream economists have tried to relieve discomfort with the looseness that is inherent in their doings by replacing concatenate coordination with "efficiency," "optimality," and "the social welfare function." These are served up as precise and accurate maximands, but in fact they often become vague and indeterminate when put to important social purposes. In our view, economists should resist translating concatenate coordination as efficiency or optimality precisely because coordination does not pretend to or aspire to a maximand.

When an economist says, "Rent control hurts coordination," the statement addresses certain narrow consequences of rent control as well as the concept of coordination itself; in making the statement, the economist aims to edify listeners with regard to the relevant moral and aesthetic sensibilities. In his book Adam Smith and the Virtues of Enlightenment, Charles Griswold (1999) writes that Smith's "work evinces a sophisticated awareness of the problem of the relationship between form, content, and audience" (p.41), and that his discourse "is intended to persuade us to view things in a certain light, to refine the ways in which we judge and feel, and perhaps to encourage us to act in a certain manner" (p.49). Griswold thusly 
characterizes Smith's discourse as protreptic - a term that refers back to Greek discourse that endeavored to persuade students, whose basic outlook and attitudes are still formative, to come to a favored way of viewing the whole matter, both "cause" and "effect" and their relations in one encompassing formulation, in preference to competing formulations, attitudes, and outlooks. Griswold views the "invisible hand" in just this way:

Just as the "invisible hand of Jupiter" was part of the vocabulary of ancient 'superstition," the 'invisible hand' is part of Smith's philosophical and protreptic rhetoric whose purpose is likewise to establish order persuasively. The many 'teleological' or even, on occasion, 'religious' statements in The Theory of Moral Sentiments must be understood in connection with this aestheticized speculative outlook.

(Griswold, 1999, p.333)

The economics literature that used "coordination" in discussing the vast concatenation had a similar protreptic quality, in that it addressed the aesthetic sensibilities that ponder the vast concatenation. The protreptic quality - addressed to edification of basic attitudes, aesthetics, and outlooks - did not fit the "value-free" values of putatively scientific economics, and hence was discouraged and displaced by more formal discourse. In the modernist century, each journal article or textbook chapter arranged for itself a neat setting and story, and "efficiency," "optimality," and "the social welfare function" were represented in those analytic settings. Yet, as game theorists from John von Neumann (Dore et al., 1989, p.xiv) to Robert Aumann (1985, p.42) have acknowledged, there is an aesthetic lurking behind such genres as well. The problem is that modelbuilding aesthetics are typically ill-suited to addressing important social purposes. If we are going to make the aesthetic element accountable to important social purpose, we ought not to keep it in the dark.

Kirzner writes: "What is needed for an objectively-based normative economics, is a criterion which, like the criteria which identify a particular disease, can be unambiguously identified by economic science and which, again as in the case of disease, seems likely to be able to serve as a norm for goodness in the light of independently established, widely shared or otherwise assumed moral 
principles" (2000, p.134). Kirzner writes as though "disease" is hammered out by science, and then the business of human affairs puts that learning to use. Similarly, he thinks that science hammers out the coordination criterion, and then the morally relevant community may adopt the criterion as a norm in evaluating policies. But the separation is false and unnatural. If the morally relevant public did not perceive beauty to inhere in coordination, what sense would it make to use that protreptic term? Suppose the morally relevant public was virulently closed and illiberal. What kind of discourse situation would have an economist talking to them of coordination (whatever it is, but assuming it is broadly liberal) and calling it "coordination"? The auditors might listen to him and say, "Ah, thank you, now we understand better what we must do to achieve discoordination."

In the case of medicine, perhaps it is much easier to separate grammar and aesthetics. "Mental illness" aside, a disease is quite distinct from the organism it afflicts. It is simple to assume that we are rooting for the organism and against the disease. In social policy, however, the "disease" is societal practices, interests, and beliefs. It is often a matter of individuals being unenlightened, of their beliefs being their affliction. The dialectics of discourse drive it toward those disagreements in which interlocutors invoke sensibilities that are not so widely shared that we may usefully fashion them "objectivelybased normative economics."

Kirzner (2000, p.145) writes: "Use of the coordination criterion involves no such moral commitment at all, on anybody's part. Use of the coordination-criterion presumes that those advised by the economist are morally concerned that members of society [achieve better coordination]." But wouldn't cooperating with policymakers entail a kind of commitment to their moral concerns? If advising the makers of public policy - or using the protreptic "coordination" in teaching 19-year olds how to interpret political and economic affairs - does not often or even typically entail moral commitments, then what does?

Kirzner elaborates on how Mises presupposes a value of "consumer sovereignty" among his readers (2001, p.169). Kirzner does not deal with whether it was reasonable to suppose that "consumer sovereignty" is an unrivaled value. Specifically, he does not explore what would happen to Mises' claims under the alternative assumption that people value collectivism. What would 
"coordination" mean to them? Suppose a social democrat favors the government school system relative to a voucher system, saying that it enhances coordination. Kirzner's formal characteristics of coordination (rubrics II and III) do not help much to dispute the claim, but, more importantly, Kirzner would be unwilling to negotiate the substance of "coordination." In contrast, a Smithian would dispute the claim but be upfront that what he deems misguided are not just narrower beliefs about specific consequences but broad beliefs as well. Most likely the social democrat will make claims that must drag us into a discussion of much wider consequences, including moral, sentimental, and cultural consequences.

There is a web of tacit understanding and sensibility that bonds us as scholars trying to serve the larger purposes. We are each individual in our interpretations and judgments, and yet we are somewhat kindred with one another. That essential condition inheres at every node of discourse:

The word $I$, does not, like the word man, denote a particular class of objects, separated from all others by peculiar qualities of their own. It is far from being the name of a species, but, on the contrary, whenever it is made use of, it always denotes a precise individual, the particular person who then speaks. It may be said to be, at once, both what the logicians call, a singular, and what they call, a common term; and to join in its signification the seemingly opposite qualities of the most precise individuality, and the most extensive generalization. (Smith, 1761, p.219)

Every economics can be thought of as the thought of some imaginary composite economist, and every economist is an "I": "The words I have spoken and am yet to speak mean nothing: it is only $I$ who mean something by them" (Polanyi, 1962, p.252).

Kirzner's attitude is to relegate anything loose and vague into not-economic-science quarters. For example, when he speaks of "a possibly erroneous initial distribution of rights" (2000, p.86), it is clear that the "erroneous" is, to his mind, completely separate from economic science. But is such a relegation wise? Why is Kirzner so sure that those quarters should exist separately and distinctly from judgments of coordination? By trying to relegate looseness to other quarters, Kirzner in fact ends up with brittle 100 percent claims 
surrounded by abstruse doctrine erupting with problems. It is a bit like managing vice: Attempts to eradicate it are vain - and discoordinative.

If, instead, we allow more of the loose and vague in our idea of coordination and confess the protreptic nature of it, then our by-andlarge claims will be more robust, and we can enter more concretely and plainly into argumentation about issues, positions, and points with fewer worries about whether a particular concession upsets some axiom and fewer inhibitions about getting into waters muddied with moral, sentimental, and cultural consequences.

Economists can preserve the important presumptive claim that coordination is advanced better by free markets than by intervention, a claim true to Hayek. It is sound to see both competition and entrepreneurship as being coordinative, in that they usually - not always - bring about changes in the grand concatenation that make it better coordinated in the eyes of the humane mind imagined to behold it. Lower-cost firms replace higher-cost firms, consumers find new and better goods and services, people find more satisfaction in their work, and so on. Such general sensibilities help to justify Adam Smith's presumption of natural liberty and ultimately entail a sense of beauty "not unlike that which we ascribe to any well-contrived machine" (1790, p.326). Government intervention typically brings a variety of effects that the imagined mind regards as baneful. With the indicated modifications, the coordination teachings of the Austrian economists remain basically true and important - but it is doubtful that they remain distinctively Austrian.

\section{References}

Aumann, Robert. 1985. "What Is Game Theory Trying to Accomplish?” In Frontiers of Economics, ed. Kenneth Arrow and Seppo Honkapohja, 28-76. Oxford: Basil Blackwell.

Boettke, Peter J. 2001. Calculation and Coordination: Essays on Socialism and Transitional Political Economy. New York: Routledge.

Buchanan, James M. 1979. "Natural and Artifactual Man." In What Should Economists Do?, 93-112. Indianapolis: Liberty Fund.

Coase, Ronald. H. 1937. "The Nature of the Firm." Economica, 4(16): 386-405. 
Coase, Ronald H. 1976. "Adam Smith's View of Man." In Essays on Economics and Economists, 95-116. Chicago: University of Chicago Press, 1994.

Coase, Ronald H. 1977. "Economics and Contiguous Disciplines." In Essays on Economics and Economists, 34-46. Chicago: University of Chicago Press, 1994.

Dore, Mohammed, Sukhamoy Chakravarty and Richard Goodwin. 1989. John von Neumann and Modern Economics. Oxford: Clarendon Press.

Griswold, Charles L. Jr. 1999. Adam Smith and the Virtues of Enlightenment. Cambridge: Cambridge University Press.

Hayek, Friedrich A. 1933a. "The Trend of Economic Thinking." Economica, 40: 121-137.

Hayek, Friedrich A. 1933b. "Price Expectations, Monetary Disturbances and Malinvestment." In Profits, Interest and Investment, 135-156. London: George Routledge and Sons, 1939.

Hayek, Friedrich A. 1937. "Economics and Knowledge." In Individualism and Economic Order, 33-56. Chicago: University of Chicago Press, 1948.

Hayek, Friedrich A. 1939. "Freedom and the Economic System." In Socialism and War, 189-211. Chicago: University of Chicago Press, 1997.

Hayek, Friedrich A. 1941. "The Economics of Planning." In Socialism and War, 141-147. Chicago: University of Chicago Press, 1997.

Hayek, Friedrich A. 1948. "The Use of Knowledge in Society." In Individualism and Economic Order, 77-91. Chicago: University of Chicago Press. (Orig. pub. 1945.)

Hayek, Friedrich A. 1952. The Sensory Order: An Inquiry into the Foundations of Theoretical Psychology. Chicago: University of Chicago Press.

Hayek, Friedrich A. 1963. "Rules, Perceptions, and Intelligibility." In Studies in Philosophy, Politics and Economics, 43-65. Chicago: University of Chicago Press, 1967.

Hayek, Friedrich A. 1973. Law, Legislation and Liberty, Volume 1: Rules and Order. Chicago: University of Chicago Press.

Hayek, Friedrich A. 1978a. "Coping with Ignorance." Imprimis, 7(7): 1-6. https://www.hillsdale.edu/news/imprimis/archive/issue.asp?year=197 $8 \&$ month $=07$

Hayek, Friedrich A. 1978b. Foreword to Ludwig von Mises's Socialism. Indianapolis: Liberty Fund, 1981. 
Hayek, Friedrich A. 1978c. "Competition as a Discovery Procedure." In New Studies in Philosophy, Politics, Economics and the History of Ideas, 179-190. Chicago: University of Chicago Press.

Hayek, Friedrich A. 1983. "An Interview with F.A. Hayek." Cato Policy Report 5(2). http://www.cato.org/pubs/policy_report/cpr-5n2hayek.html

Hayek, Friedrich A. 1994. Hayek on Hayek: An Autobiographical Dialogue. Chicago: University of Chicago Press.

High, Jack C. 1982. "Alertness and Judgment: Comment on Kirzner.” In Method, Process, and Austrian Economics, ed. Israel M. Kirzner, 161-168. Lexington, MA: D.C. Heath.

Hutt, W.H. 1934. "Co-ordination and the Size of the Firm." South African Journal of Economics, 2(4): 383-402.

Ikeda, Sanford. 1990. "Market-Process Theory and 'Dynamic' Theories of the Market." Southern Economic Journal, 57(1): 75-92.

Jakee, Keith, and Heath Spong. 2003. "Praxeology, Entrepreneurship and the Market Process: A Review of Kirzner's Contribution." Journal of the History of Economic Thought, 25(4): 461-486.

Keynes, John M. 1930. Treatise on Money I. London: Macmillan.

Kirzner, Israel M. 1963. Market Theory and the Price System. Princeton, NJ: Van Nostrand.

Kirzner, Israel M. 1973. Competition and Entrepreneurship. Chicago: University of Chicago Press.

Kirzner, Israel M. 1979. Perception, Opportunity, and Profit: Studies in the Theory of Entrepreneurship. Chicago: University of Chicago Press.

Kirzner, Israel M. 1983. "Does Anyone Listen to Economists?” Inquiry: A Libertarian Review. April, 38-40.

Kirzner, Israel M. 1985. Discovery and the Capitalist Process. Chicago: University of Chicago Press.

Kirzner, Israel M. 1992a. The Meaning of Market Process: Essays in the Development of Modern Austrian Economics. New York: Routledge.

Kirzner, Israel M. 1992b. "Entrepreneurship, Uncertainty and Austrian Economics: Commentary on Ricketts." In Austrian Economics: Tensions and New Directions, ed. Bruce J. Caldwell and Stephan Boehm, 85-102. Boston: Kluwer Academic Publishers. 
Kirzner, Israel M. 1994. "A Tale of Two Worlds: Comment on Shmanske." In Advances in Austrian Economics, Vol. 1, ed. Peter J. Boettke and Mario Rizzo, 223-226. Greenwich, Connecticut: JAI Press.

Kirzner, Israel M. 2000. The Driving Force of the Market. New York: Routledge.

Kirzner, Israel M. 2001. Ludwig von Mises: The Man and His Economics. Wilmington, DE: ISI Books.

Klein, Daniel B. 1997a. "Convention, Social Order, and the Two Coordinations." Constitutional Political Economy, 8(4): 319-335.

Klein, Daniel B. 1997b. "Discovery Factors of Economic Freedom: Respondence, Epiphany, and Serendipity." In Uncertainty and Economic Evolution: Essays in Honor of Armen A. Alchian, ed. John R. Lott, Jr., 165-180. New York: Routledge.

Klein, Daniel B. 1998. "Planning and the Two Coordinations, With Illustration in Urban Transit." Planning and Markets, 1(1). http://wwwpam.usc.edu/volume1/v1i1a1s1.html

Klein, Daniel B. 1999. "Discovery and the Deepself." Review of Austrian Economics, 11: 47-76.

Klein, Daniel B., and Aaron Orsborn. 2008. "Concatenate Coordination and Mutual Coordination." Ratio Institute Working Paper 116. http://www.ratio.se/pdf/wp/dk_ao_coordination.pdf

Klein, Peter G. Forthcoming. "Opportunity Discovery, Entrepreneurial Action, and Economic Organization." Strategic Entrepreneurship Journal. http://papers.ssrn.com/sol3/papers.cfm?abstract_id=1141549

Knight, Frank H. 1921. Risk, Uncertainty, and Profit. Boston: Houghton Mifflin Company.

Loasby, Brian J. 1982. "Economics of Dispersed and Incomplete Information." In Method, Process, and Austrian Economics: Essays in Honor of Ludwig von Mises, ed. Israel M. Kirzner, 111-130. Lexington, MA: DC Heath.

Loasby, Brian J. 1983. "Knowledge, Learning and Enterprise." In Beyond Positive Economics, ed. Jack Wiseman, 104-121. London: Macmillan.

Maugham, W. Somerset. 1952. "The Verger." In The Complete Short Stories of W. Somerset Maugham, Vol. III, 572-578. Garden City, New York: Doubleday.

Mises, Ludwig von. 1966. Human Action: A Treatise on Economics. 3rd ed. Chicago: Henry Regnery. (Orig. pub. 1949.) 
Mises, Ludwig von. 1981. Socialism: An Economic and Sociological Analysis, trans. J. Kahane. Indianapolis: Liberty Fund. (Orig. pub. 1922.) http://www.econlib.org/Library/Mises/msS.html

Newcomb, Simon. 1880a. "The Organization of Labor I: The Organizer as a Producer." Princeton Review, 1: 393-410.

Newcomb, Simon. 1880b. The Organization of Labor II: The Interest of the Laborer in Production. Princeton Review, 2: 231-46.

Newcomb, Simon. 1886. Principles of Political Economy. New York: Harper \& Brothers.

Peterson, G. Shorey. 1930. "Transport Co-ordination: Meaning and Purpose." Journal of Political Economy, 38(6): 660-681.

Plant, Arnold. 1937. “Centralise or Decentralise?” In Selected Economic Essays and Addresses, 174-198. London: Routledge \& Kegan Paul, 1974.

Polanyi, Michael. 1962. Personal Knowledge: Towards a Post-Critical Philosophy. Chicago: University of Chicago Press.

Quine, Willard van Orman. 1961. "Two Dogmas of Empiricism." In From a Logical Point of View. 2nd ed., 20-46. Cambridge: Harvard University Press.

Ricketts, Martin. 1992. “Kirzner's Theory of Entrepreneurship - A Critique." In Austrian Economics: Tensions and New Directions, ed. Bruce J. Caldwell and Stephan Boehm, 67-102. Boston: Kluwer.

Ricketts, Martin. 1994. The Economics of Business Enterprise: An Introduction to Economic Organization and the Theory of the Firm. 2nd ed. New York: Harvester Wheatsheaf.

Rothbard, Murray N. 1956. "Toward a Reconstruction of Utility and Welfare Economics." In On Freedom and Free Enterprise, ed. Mary Sennholz, 224-262. Irvington-on-Hudson, NY: Foundation for Economic Education, 1994.

Rothbard, Murray N. 1962. Man, Economy and State: A Treatise on Economic Principles. Auburn, AL: Ludwig von Mises Institute, 1993.

Salerno, Joseph T. 1993. "Mises and Hayek Dehomogenized." Review of Austrian Economics, 6(2): 113-46.

Salerno, Joseph T. 2007. "The Entrepreneur: Real and Imagined." Paper presented at Austrian Scholars Conference, Auburn, AL. http://mises.org/journals/scholar/salerno4.pdf

Sautet, Frédéric E. 2000. An Entrepreneurial Theory of the Firm. London: Routledge. 
D. B. Klein and J. Briggeman / The Journal of Private Enterprise 25(2), 2010, 1-53

Schumpeter, Joseph A. 1934. The Theory of Economic Development, trans. R. Opie. Cambridge: Harvard University Press.

Selgin, George A. 1983. "Praxeology and Understanding: An Analysis of the Controversy in Austrian Economics." Review of Austrian Economics, 2(1): 19-58.

Shearmur, Jeremy. 1996. Hayek and After: Hayekian Liberalism as a Research Programme. London: Routledge.

Smith, Adam. 1761. "Considerations Concerning the First Formation of Languages." In Glasgow Edition of the Works and Correspondence Vol. 4 Lectures on Rhetoric and Belles Lettres, ed. J. C. Bryce, 203-226. Indianapolis: Liberty Fund, 1985.

Smith, Adam. 1776. An Inquiry into the Nature and Causes of the Wealth of Nations. Oxford: Oxford University Press, 1976.

Smith, Adam. 1790. The Theory of Moral Sentiments. Indianapolis: Liberty Fund, 1982.

Spencer, Herbert. 1862. First Principles. New York: D. Appleton.

Thomsen, Estaban. 1992. Prices and Knowledge: A Market-Process Perspective. London: Routledge. 